\title{
Therapeutic targeting of Lyn kinase to treat chorea-acanthocytosis
}

\author{
Kevin Peikert ${ }^{1,19 \dagger}$, Enrica Federti ${ }^{2 \dagger}$, Alessandro Matte ${ }^{2}$, Gabriela Constantin ${ }^{2}$, Enrica Caterina Pietronigro ${ }^{2}$, \\ Paolo Francesco Fabene ${ }^{3}$, Paola Defilippi ${ }^{4}$, Emilia Turco ${ }^{4}$, Federico Del Gallo ${ }^{3}$, Pietro Pucci ${ }^{5,21}$, \\ Angela Amoresano ${ }^{5}$, Anna Illiano ${ }^{5}$, Flora Cozzolino ${ }^{5,21}$, Maria Monti ${ }^{5,21}$, Francesca Garello ${ }^{6}$, Enzo Terreno ${ }^{6}$, \\ Seth Leo Alper ${ }^{7}$, Hannes Glaß ${ }^{1}$, Lisann Pelzl ${ }^{8,9}$, Katja Akgün ${ }^{10}$, Tjalf Ziemssen ${ }^{10}$, Rainer Ordemann ${ }^{11}$, \\ Florian Lang ${ }^{8}$, Anna Maria Brunati ${ }^{12}$, Elena Tibaldi1 ${ }^{12}$, Immacolata Andolfo ${ }^{13,21}$, Achille lolascon ${ }^{13,21}$, \\ Giuseppe Bertini ${ }^{3}$, Mario Buffelli ${ }^{3}$, Carlo Zancanaro ${ }^{3}$, Erika Lorenzetto ${ }^{3,17}$, Angela Siciliano2, \\ Massimiliano Bonifacio ${ }^{2}$, Adrian Danek ${ }^{15}$, Ruth Helen Walker ${ }^{14,16}$, Andreas Hermann ${ }^{1,18,19,20^{*}+}$ and \\ Lucia De Franceschi ${ }^{2 *}+(0)$
}

\begin{abstract}
Chorea-Acanthocytosis (ChAc) is a devastating, little understood, and currently untreatable neurodegenerative disease caused by VPS13A mutations. Based on our recent demonstration that accumulation of activated Lyn tyrosine kinase is a key pathophysiological event in human ChAc cells, we took advantage of Vps $13 a^{-1-}$ mice, which phenocopied human ChAc. Using proteomic approach, we found accumulation of active Lyn, $\gamma$-synuclein and phospho-tau proteins in $\mathrm{Vps} 13 a^{-1-}$ basal ganglia secondary to impaired autophagy leading to neuroinflammation. Mice double

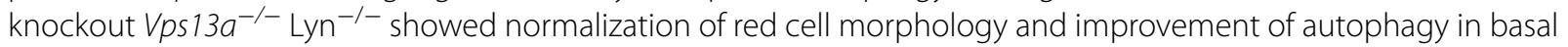
ganglia. We then in vivo tested pharmacologic inhibitors of Lyn: dasatinib and nilotinib. Dasatinib failed to cross the mouse brain blood barrier (BBB), but the more specific Lyn kinase inhibitor nilotinib, crosses the BBB. Nilotinib ameliorates both Vps $13 a^{-/-}$hematological and neurological phenotypes, improving autophagy and preventing neuroinflammation. Our data support the proposal to repurpose nilotinib as new therapeutic option for ChAc patients.
\end{abstract}

Keywords: Chorein, Lyn, Cell signaling, Basal ganglia, Neurodegeneration

\section{Introduction}

The ultra-rare neurodegenerative disease Chorea-Acanthocytosis (ChAc) with 1000-5000 cases worldwide is one of the core neuroacanthocytosis syndromes (NA) [26,

\footnotetext{
*Correspondence: Andreas.Hermann@med.uni-rostock.de; lucia.defranceschi@univr.it

${ }^{t}$ Kevin Peikert, Enrica Federti, Andreas Hermann and Lucia De Franceschi have contributed equally to this work

1 Translational Neurodegeneration Section "Albrecht-Kossel", Department of Neurology, University Medical Center Rostock, University of Rostock, Gehlsheimer Straße 20, 18147 Rostock, Germany

${ }^{2}$ Department of Medicine, University of Verona, Policlinico GB Rossi, P.Le L. Scuro, 10, 37134 Verona, Italy

Full list of author information is available at the end of the article
}

50, 70]. NA diseases manifest with a spectrum of neurological symptoms in addition to the presence of misshaped red blood cells (RBCs) with thornlike protrusions, referred to as acanthocytes [7, 26, 35, 50]. Autosomalrecessive ChAc is caused by loss-of-function mutations in the vacuolar protein sorting 13 homolog A (VPS13A) gene encoding the chorein polypeptide gene product $[8,10,54,68]$. Only symptomatic treatment is currently available to modify the devastating disease course [71] despite a shortened life-span marked by considerable morbidity and compromised independent living. These clinical manifestations are accompanied by loss of striatal medium spiny neurons [38] and a distinctive cortical original author(s) and the source, provide a link to the Creative Commons licence, and indicate if changes were made. The images or other third party material in this article are included in the article's Creative Commons licence, unless indicated otherwise in a credit line to the material. If material is not included in the article's Creative Commons licence and your intended use is not permitted by statutory regulation or exceeds the permitted use, you will need to obtain permission directly from the copyright holder. To view a copy of this licence, visit http://creativecommons.org/licenses/by/4.0/. The Creative Commons Public Domain Dedication waiver (http://creativeco mmons.org/publicdomain/zero/1.0/) applies to the data made available in this article, unless otherwise stated in a credit line to the data. 
neurodegeneration [39]. Other members of the vacuolar protein sorting (Vps) family of proteins have been linked to more common neurodegenerative disorders such as Parkinson's disease (PD) (Vps35 and Vps13c) and frontotemporal dementia (Vps4B) $[34,60]$.

ChAc patients often present with progressive movement disorders like chorea, parkinsonism and/or dystonia $[13,53,70]$. Therefore, ChAc should be considered as a relevant differential diagnosis of Huntington's disease (HD) [22]. This disease severely affects independent living, and results in significant morbidity and a markedly reduced life-span [71].

Although studies in mammalian cell lines and in model organisms such as yeast suggest that chorein's possible function as a lipid transporter at organelle contact sites, possibly mediating non-vesicular phospholipid transport $[14,32,74]$, the function of chorein remains incompletely understood. We recently identified accumulation of active Lyn, a kinase of the Src family tyrosine kinases as key driver of ChAc pathophysiology (for review see [50]). We also found that Lyn inhibition by PP2 or dasatinib (1) ameliorates the distorted erythroid morphology and other altered red cell features in vitro; and (2) ameliorates the pathologically increased synaptic transmission in striatal medium spiny neurons generated from ChAc iPSCs $[9,42,64]$. The proteotoxic effect of Lyn gain-offunction reflects impaired autophagy, in agreement with VPS13A-deficient cell models.

Here, we studied Vps13a ${ }^{-1-}$ mice lacking chorein. $\mathrm{Vps}_{13 \mathrm{a}^{-1-}}$ mice display biological features of human ChAc. We confirmed the accumulation of active Lyn in both RBCs and basal ganglia of $\mathrm{Vps}_{13 \mathrm{a}^{-/-}}$mice, associated with impaired autophagy and accumulation of phospho-Tau proteins and $\gamma$-synuclein. Dasatinib treatment of $\mathrm{Vps13}^{-1-}$ mice blocked Lyn activity in RBCs but not in the basal ganglia. Mass spectrometric analysis revealed that dasatinib did not accumulate to detectable levels in basal ganglia, thus providing one potential explanation for the absence of an effect of dasatinib on neurologic phenotype of ChAc patients. We therefore tested the second generation TKI nilotinib, with higher selectivity for Lyn and able to cross the blood-brain barrier (BBB) [21]. We showed that nilotinib reached the basal ganglia, where it inhibited Lyn and improved autophagy, neuronal loss and neuroinflammation.

\section{Materials and methods}

\section{Mouse model for ChAc (Vps13a ${ }^{-l-}$ mice)}

Experiments were performed on age and gendermatched WT (C57BL/6J) and Vps13a ${ }^{-1-}$ mice and on 12 months-old sex-matched $\mathrm{Vps} 13 \mathrm{a}^{-/-} \mathrm{Lyn}^{-/-}$mice. We obtained Vps13a heterozygous knock out $( \pm)$ mice from the EMMA Consortium (Additional file 1: Fig. S1).
Vps13a ${ }^{-1-} \mathrm{Lyn}^{-1-}$ mice were generated in house backcrossing for at least 16 generation $\mathrm{Vps}_{13 \mathrm{a}^{-/-}}$mice and $\mathrm{Lyn}^{-1-}$ mice. The Institutional Animal Experimental Committee of University of Verona (CIRSAL) approved the experimental protocol. Whenever indicated WT and Vps13a $\mathrm{a}^{-1-}$ mice were daily treated with vehicle (tap water) or dasatinib or nilotinib. Dasatinib $(50 \mathrm{mg} / \mathrm{Kg}$ ) was administered by daily gavage to 12 months-old mice for 1 month. Nilotinib $(25 \mathrm{mg} / \mathrm{Kg} /$ day $)$ was administered by gavage to 11 months-old Vps13a ${ }^{-/-}$mice for either 6 weeks or 3 months or 6 months. This dosage was chosen based on a previous report on a mouse model for PD and $\mathrm{AD}[20,40]$. Isoflurane-anesthetized mice were randomly assigned to experimental groups and blindly analyzed. Hematologic parameters and red cell indices were evaluated on a Siemens ADVIA 2120 hematology analyzer. Hematocrit and hemoglobin were manually determined [27, 43, 44]. Acanthocyte evaluation and counting were performed on McGrawald-Giemsa-stained blood smears and by electron microscopy [42]. Brains immediately removed from euthanized mice were dissected to isolate basal ganglia (BG) and cortex tissues, which were instantly frozen in liquid nitrogen.

\section{Statistical analysis}

Statistical analysis was performed with the GraphPad Prism 8.0 program. Data were analyzed using either $t$-test or one-way ANOVA (Dunnet's test) for longitudinal studies or 2-way analysis of variance (ANOVA) with Bonferroni connection for repeated measures among mice of different genotypes. $p<0.05$ was considered significant.

\section{Behaviour test}

Comparisons between two groups were performed using the two-tailed unpaired Student's $t$-test. Data were expressed as the mean \pm SEM. Statistical significance was accepted at the $95 \%$ confidence level $(p<0.05)$. Spontaneous locomotor activity was evaluated using a two-way mixed-model ANOVA (strain*day) followed by the Bonferroni post hoc test. For the analysis of gait parameters, the means of the hind and front paws and individual paws were considered. The individual averages for each mouse were calculated over three good runs (straightforward and without hesitations), and the differences between groups were evaluated with a two-tailed unpaired Student's $t$-test. Statistical significance was accepted at the 95\% confidence level $(p<0.05)$.

\section{Immunofluorescence microscopy}

Quantification of NeuN positive cells and Iba1 positive cells was followed by statistical analyses applying twotailed Unpaired $t$ test. Data are shown as mean \pm SEM. 
Quantification of beclin1-positive and $\gamma$-Synucleinpositive cells were followed by a statistical analysis. Statistically significant differences between the two nonparametric data sets were assessed by Mann-Whitney's test. Statistical significance was determined at $p<0.05$.

\section{Brain spectroscopy}

Comparisons between two groups were performed using the two-tailed unpaired Student's $t$-test. Data were expressed as the mean \pm SEM. Statistical significance was accepted at the $95 \%$ confidence level $(P<0.05)$.

\section{NanoLC/MS-MS analysis}

Statistical analysis was performed in $\mathrm{MeV}$ using a Student's two tailed t-test. Statistical significance was determined at $P<0.05$.

\section{Results \\ $\mathrm{Vps} 13 \mathrm{a}^{-/-}$mice recapitulate key features of patients suffering from $\mathrm{ChAc}$}

Survival of $\mathrm{Vps} 13 \mathrm{a}^{-1-}$ mice was significantly reduced compared to wild-type animals as assessed by log-rank test analysis (Additional file 1: Fig. S1.2A). Weights of both male and female $V p s 13 a^{-/-}$mice of across all ages were lower than those of wild-type animals (Additional file 1: Fig. S1.2B).

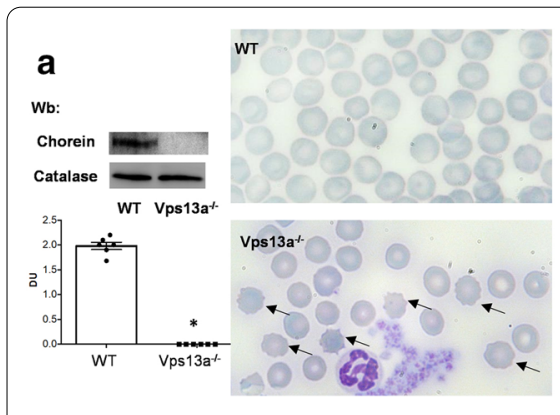

b

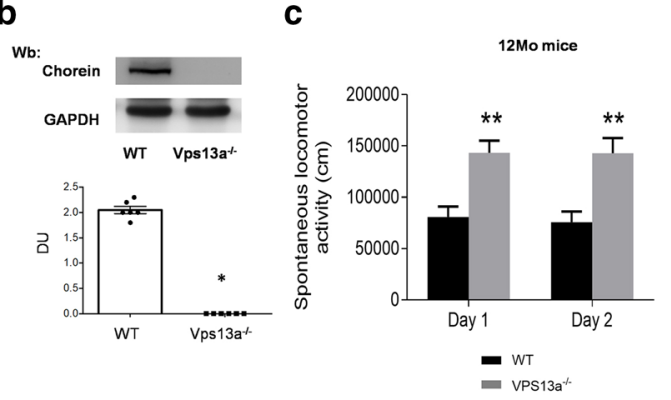

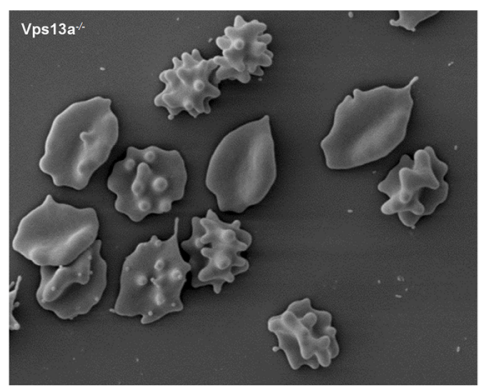
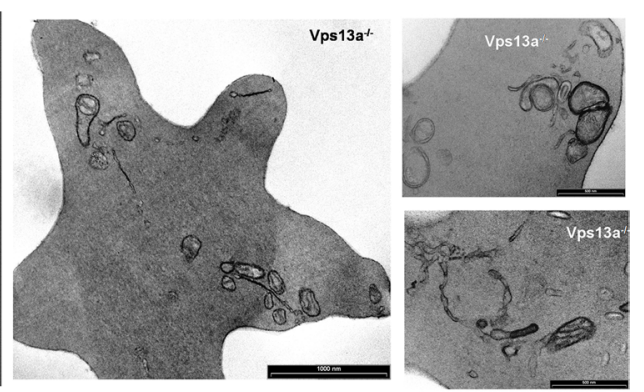

d
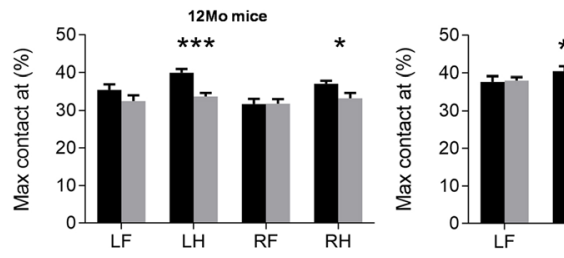

18Mo mice

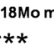

e
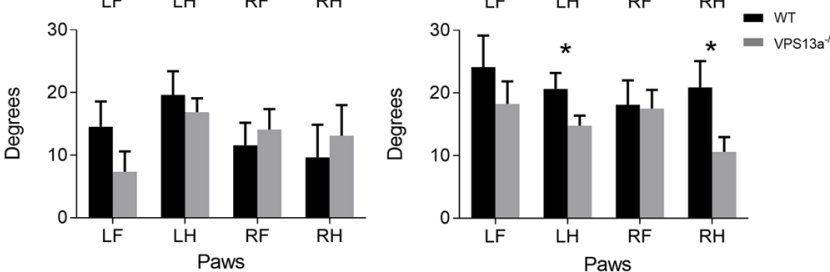

Fig. 1 Vps $13 a^{-/-}$mice exhibit hematologic and neurologic features similar to those in human ChAc. a Left panel. Western blot (Wb) analysis of chorein in red cells of WT and Vps13a-/- mice. Catalase served as protein loading control. Lower panel. Densitometric analysis (arbitrary units) of immunoblot bands like those shown; means $\pm \operatorname{SEM}\left(n=6 ;{ }^{*} p<0.001\right.$ vs. WT by t-test). Right panel (from left to right). Morphologic analysis of peripheral blood from wild-type (WT) and Vps13a-/- mice. Blood smears stained with May-Grunwald-Giemsa. Cells were imaged under oil at $100 \times$ magnification using Panfluor objective 1.30 numeric aperture on a Nikon Eclipse DS-5 M camera and processed with Digital Slide (DS-L1) Nikon. Black arrows indicate acanthocytes in Vps13a $a^{-1-}$ mice. (see also Additional file 1: Fig. S4.2C). Electron microscopy of circulating red cells from $\mathrm{Vps} 13 \mathrm{a}^{-/-}$mice. The image is representative of 10 similar imaged visual fields for each of $10 \mathrm{Vps} 13 \mathrm{a}^{-1-}$ mice at the ages of 12 months. $\mathbf{b}$ Western blot (Wb) analysis of Chorein in isolated basal ganglia of wild-type (WT) and Vps13a ${ }^{-/}$mice. GADPH is the loading control. Densitometric analysis (arbitrary units) of the immunoblot bands similar to those shown are presented (bottom); data are means \pm SEM $\left(n=6\right.$; ${ }^{*} P<0.001$ vs. WT by t-test). $\mathbf{c}$ Spontaneous locomotor activity in Vps $13 \mathrm{a}^{-/-}$and wild-type mice in undisturbed conditions. At 12 months mice were maintained in a PhenoTyper ${ }^{\circledR}$ cage $\left(\right.$ Noldus ${ }^{\circledR}$ ) and continuously monitored for two consecutive days (Day 1 and Day 2). Data represent the mean \pm SEM of the total distance moved $(\mathrm{cm})$ per day ${ }^{* *} P<0.01$ vs. wild-type mice, $\mathrm{n}=6$ animals per group). $\mathbf{d}$ CatWalk ${ }^{\circledR}$ gait analysis of $\mathrm{Vps} 13 \mathrm{a}^{-1-}$ and wild-type mice. The data represent the mean \pm SEM of three runs per animal and are presented per each paw, left front (LF), left hind (LH), right front (RF) and right hind (RH) $\left({ }^{*} p<0.05,{ }^{* *} P<0.01,{ }^{* * *} P<0.001 ; \mathrm{n}: 19 \mathrm{Vps} 13 \mathrm{a}^{-/-}\right.$mice, $\mathrm{n}: 15$ wild-type mice) (see also Additional file 1: Fig. S5A). At $18 \mathrm{months}$ of age Vps13a ${ }^{-/-}$ mice showed a deviating paw angle of both hind paws compared to controls $* P<0.05 ; n=19 \mathrm{Vps} 13 \mathrm{a}^{-/-}$mice, $\mathrm{n}=15$ wild-type mice) 


\section{Hematologic phenotype}

Chorein expression was undetectable in $\mathrm{Vps} 13 \mathrm{a}^{-1-}$ mouse RBCs (Fig. 1a). Acanthocytes were observed by multiple imaging approaches (Fig. 1a). The numbers of acanthocytes in $V p s 13 a^{-/-}$mice were stable beyond age 2 months, considered as adult subjects from the perspective of hematologic development (Additional file 1: Fig. $\mathrm{S} 1.2 \mathrm{C}$ ). No major differences in hematologic parameters or red cell indices were observed in $\mathrm{Vps}_{13} \mathrm{a}^{-1-}$ mice compared to wild-type animals with the exception of the $\mathrm{Hb}$ distribution width (HDW), useful to evaluate acanthocytes (Table 1). HDW was significantly increased in $\mathrm{Vps}_{13 \mathrm{a}^{-1-}}$ mice compared to wild-type animals (Table 1). We fractionated RBCs as a function of cell $\mathrm{Hb}$ content and cell volume $(\mathrm{V} / \mathrm{HC})$, revealing a dense cell

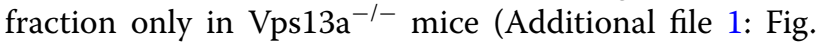
$\mathrm{S} 1.2 \mathrm{C}$, lower panel, blue circle). This fraction contains acanthocytes similarly to those observed in human ChAc [42]. As like human $\mathrm{ChAc}$, osmotic fragility of $\mathrm{Vps} 13 \mathrm{a}^{-/-}$ mouse RBCs was higher than in wild-type RBCs (Additional file 1: Fig. S1.2D). This was associated with reduced $\mathrm{K}^{+}$content in $V p s 13 a^{-/-} \mathrm{RBCs}$ as compared to healthy mouse RBCs (WT mice $460 \pm 12 \mathrm{mmol} / \mathrm{Kg} \mathrm{Hb}$ vs. $V p s 13 a^{-/-}$mice $350 \pm 8.1 \mathrm{mmol} / \mathrm{Kg} \mathrm{Hb} n=6$ in each group, $\left.{ }^{*} p<0.05\right)$, resembling again the human disease [5].

In $\mathrm{Vps} 13 \mathrm{a}^{-/-}$mouse RBCs, we found accumulation of active Lyn compared to wild-type erythrocytes (Additional file 1: Fig. S1.2E). This increase was associated with retention of double membrane remnants and vesicles, indicating an impairment of autophagy (Fig. 1a). In agreement with the morphological findings, we observed accumulation of Ulk1, Atg4, Atg5 and Rab5 polypeptides, as seen in human ChAc RBCs [42] (Additional file 1: Fig. $\mathrm{S} 1.2 \mathrm{~F})$. Taken together these data recapitulate key hematologic features of ChAc patients.

Table 1 Hematological parameters and red cell indices in wildtype and $\mathrm{Vps} 13 \mathrm{a}^{-/-}$mice

\begin{tabular}{lll}
\hline & $\begin{array}{l}\text { Wild-type mice } \\
(\boldsymbol{n}=\mathbf{1 2})\end{array}$ & $\begin{array}{l}\text { Vps13a }^{-1-} \text { mice } \\
(\boldsymbol{n}=\mathbf{1 2})\end{array}$ \\
\hline $\mathrm{HCt}(\%)$ & $45.3 \pm 1.2$ & $46.1 \pm 0.8$ \\
$\mathrm{Hb}(\mathrm{g} / \mathrm{dl})$ & $14.9 \pm 0.3$ & $14.2 \pm 0.6$ \\
$\mathrm{MCV}(\mathrm{fl})$ & $52.4 \pm 1.6$ & $53.1 \pm 1.5$ \\
MCH (pg) & $16.3 \pm 0.8$ & $15.9 \pm 0.8$ \\
$\mathrm{CHCM}(\mathrm{g} / \mathrm{dL})$ & $26.3 \pm 0.2$ & $26.2 \pm 0.2$ \\
RDW (\%) & $12.5 \pm 0.4$ & $12.9 \pm 0.7$ \\
HDW (g/dL) & $2.1 \pm 0.43$ & $\mathbf{3 . 1} \pm \mathbf{0 . 4 7 *}$ \\
Retics (cell/uL) & $417 \pm 65$ & $382 \pm 84$
\end{tabular}

Hct haematocrit, $H b$ haemoglobin, $M C V$ mean corpuscular volume, $M C H$ mean corpuscular haemoglobin, CHCM cell hemoglobin mean content, $R D W$ red cell distribution width, HDW hemoglobin distribution width, Retics reticulocytes ${ }^{*} p<0.05$ compared to wild-type mice

\section{Neurologic phenotype}

Chorein was undetectable in isolated basal ganglia from saline buffer-perfused 12- and 18-months old $V p s 13 a^{-/-}$ mice (Fig. 1b). Gait and motor assessment were performed in cohorts of $\mathrm{Vps} 13 \mathrm{a}^{-/-}(\mathrm{n}: 19)$ and wild-type (n:15) mice at 12 and 18 months. Anxiety trait and spontaneous locomotor activity were assessed in a subgroup (n:6 for each strain) of both mouse strains (12 monthsold only) applying a 5-min protocol using elevated-plus maze (EPM). No significant differences were found in the time spent in the closed and open arms (an index related to a more or a less anxiety trait) between $\mathrm{Vps} 13 \mathrm{a}^{-1-}$ and wild-type mice. The spontaneous locomotor activity was continuously monitored for two days by video-tracking observations of individual 12 months-old mice in PhenoTyper cages, which allowed home-cage evaluation of locomotor activity, unaffected by anxiety and/or stress of a test cage environment. The overall distance covered by the $\mathrm{Vps} 13 \mathrm{a}^{-1-}$ mice was significantly higher (day 1: $82.48 \pm 11.68 \%, p<0.01$; day $2: 100.29 \pm 11.68 \%$, $p<0.01)$ compared to that of age-matched wild-type mice (Fig. 1c). $\mathrm{Vps}_{13 \mathrm{a}^{-1-}}$ mice and matched wild-type mice were tested for their spontaneous gait behavior (Fig. 1d). The gait performance of $\mathrm{Vps} 13 \mathrm{a}^{-/-}$mice was affected during the test session at both 12 and 18 months of age. In particular, starting from 12 months, $\mathrm{Vps} 13 \mathrm{a}^{-1-}$ mice showed a longer duration from the start of a run until maximum contact occurs for both hind paws compared to age- and weight-matched control mice (see also Additional file 1: Fig. S2A for schematic diagram of the angle evaluation). The delay in reaching the maximum contact of paws with a glass plate was also observed at older age (Fig. 1d). Also, at 18 months, but not at 12 months (Fig. 1d), $\mathrm{Vps} 13 \mathrm{a}^{-1-}$ mice showed a different paw angle of both hind paws (Fig. 1d). A similar discrepancy in paw angle was reported in a transgenic rat model for Huntington's disease [69]. "Max contact at (\%)" refers to the duration, from the start of a run, until maximum contact of paws occurs. This index has been largely studied in rodent models in the context of parkinsonism $[2,3]$. The basal ganglia of these aged $V p s 13 a^{-1-}$ mice exhibited accumulation of active Lyn as compared to wild-type animals (Additional file 1: Fig. S2B, C), in agreement with our previous report on active Lyn accumulation in neuronal cells derived from ChAc iPSC [64]. We note, in particular the presence in $V p s 13 a^{-/-}$mouse basal ganglia of active Lyn stabilized in high molecular weight complexes, as earlier observed in human ChAc RBCs (Additional file 1: Fig. S2D) [42]. Collectively, our data indicate that $V p s 13 a^{-1-}$ mice recapitulate biological features and neurological phenotype like those of ChAc patients. 


\section{Vps $13 a^{-l-}$ mice show neuronal loss and neuroinflammation}

To explore neurochemical abnormalities in striatum from $\mathrm{Vps}_{13 \mathrm{a}^{-/-}}$mice by non-invasive approaches, we used proton magnetic resonance spectroscopy H-MRS $[1,11$, 31]. We found a significant reduction in $\mathrm{N}$-acetylasparate (NAA) in striatum from $\mathrm{Vps} 13 \mathrm{a}^{-1-}$ mice compared to wild-type animals, suggesting the presence of neuronal degeneration in mice genetically lacking Chorein (Fig. 2a) $[11,51]$. Histopathological studies of $\mathrm{Vps} 13 \mathrm{a}^{-/-}$mice demonstrated a significant reduction in NeuN staining in cortex compared to wild-type animals, indicating a loss of neurons (Fig. 2b).

It is noteworthy that we found increased microglia in the cortex from 12 months-old Vps $13 \mathrm{a}^{-1-}$ mice compared to wild-type animals (Fig. 2c). This was associated with increased activation of NF-kB p65 in both cortex and basal ganglia from 12 and 18 months-old Vps $13 \mathrm{a}^{-1-}$ mice compared to wild-type animals, consistent with neuroinflammation in mice genetically lacking Chorein (Fig. 2d, see also Additional file 1: Fig. S3). In agreement with this observation, we noted up-regulation of IL- $1 \beta$ mRNA expression in both cortex and basal ganglia from 12 and 18 months-old Vps13a ${ }^{-1-}$ mice compared to wildtype animals (Fig. 2e).

Taken together, our data indicate neuron loss and neuro-inflammation in $\mathrm{Vps} 13 \mathrm{a}^{-/-}$mice, highlighting similarities with other neurodegenerative diseases such as Parkinson disease [23].

\section{Vps13a- 1 - mice show impaired autophagy involving beclin-1 pathway}

To understand the possible contribution of impaired autophagy to neuronal dysfunction and

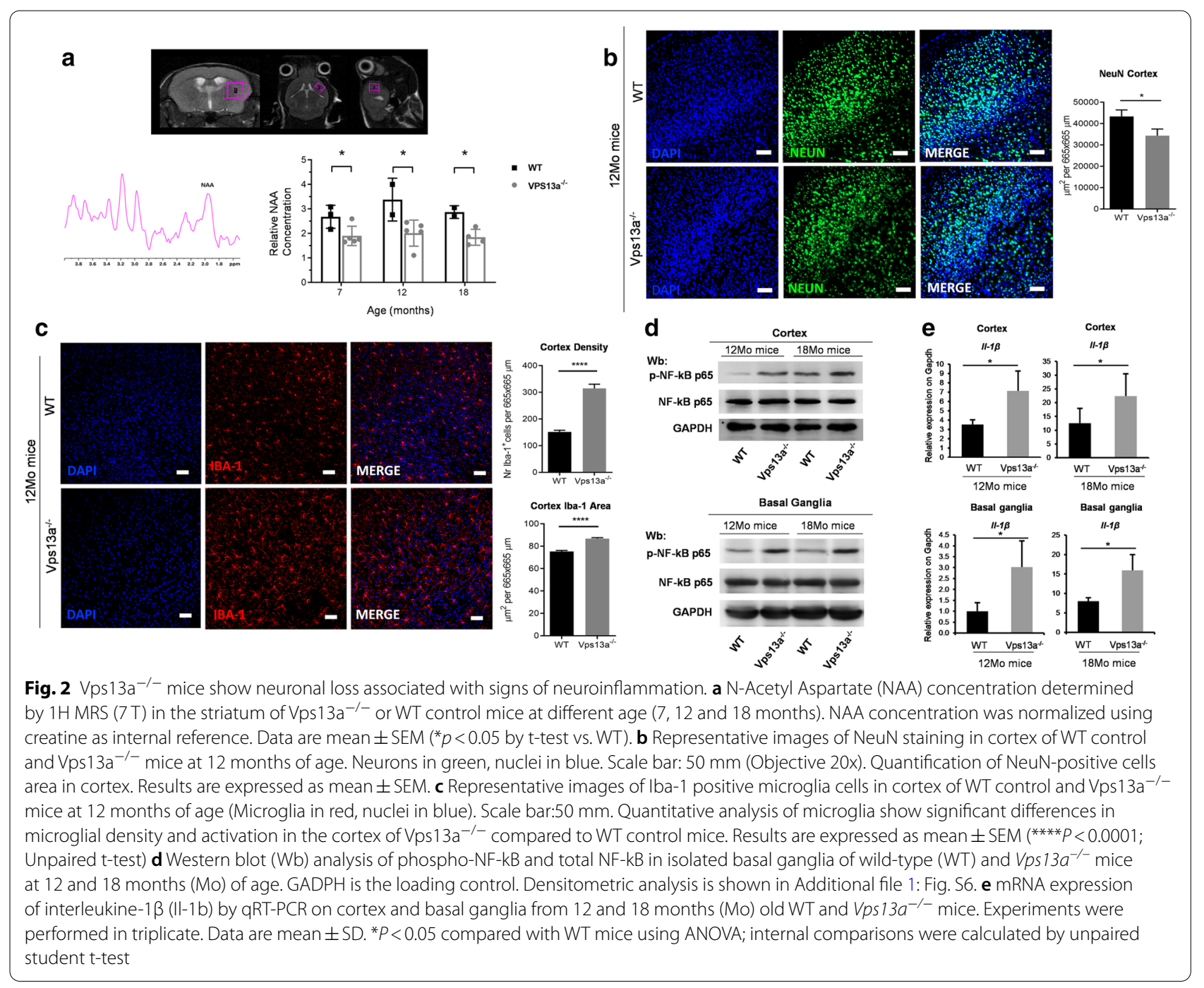


neuroinflammation in $\mathrm{Vps} 13 \mathrm{a}^{-/-}$mice, we evaluated expression of key autophagy flux proteins in isolated basal ganglia from saline buffer-perfused $\mathrm{Vps} 13 \mathrm{a}^{-1-}$ and wild-type mice. Vps13a $a^{-/-}$basal ganglia exhibited activation of LC3 II/I and significant accumulation of the following autophagy-related proteins: Ulk1, Atg4, Atg5, Atg9 and the lysosomal cargo protein p62 consistent with impairment of autophagy in Vps13a ${ }^{-1-}$ mice (Additional file 1: Fig. S4A) as described in other neurodegenerative diseases such as PD and AD [45, 56-58]. The beclin-1 system is one of the most critical hubs of the autophagic process, playing an important role in initiation and promotion of autophagy. Severe neurodegeneration and impaired autophagy have been observed in beclin $1^{-/-}$ mice, further linking beclin-1-dependent autophagy with neurodegenerative diseases $[45,58]$. In $\mathrm{Vps}_{13 \mathrm{a}^{-1-}}$ mice at 12 and 18 months of age, beclin- 1 was significantly reduced as observed by different methods (Additional file 1: Fig. S4B, C). We also observed an accumulation of the beclin-1 complex components Vps34 and Rab5 as well as of p62, a marker of late phase of autophagy (Additional file 1: Fig. S5A). To further evaluate a possible link between chorein and beclin-1, we immunoprecipitated Beclin-1 and immunoblotted for either Chorein, Atg14L or Vps34. We found Chorein co-immunoprecipitated with Beclin-1 only in basal ganglia from wild-type mice but not from $V p s 13 a^{-/-}$mice. In addition, we observed a reduction in Vps34 and Atg14L association with beclin-1 in $V p s 13 a^{-/-}$mice compared to wild-type animals (Additional file 1: Fig. S5B). Noteworthy, we found up-regulation of beclin-1 mRNA levels in isolated basal ganglia from $\mathrm{Vps}_{13 \mathrm{a}^{-1-}}$ mice compared to wild-type mice, suggesting a Beclin-1 protein degradation (Additional file 1: Fig. S5C). Since Beclin-1 levels depend on Caspase 3 activity, we evaluated Caspase- 3 activation by immunoblot analysis of total cleaved Caspase- 3 and a fluorometric assay for Caspase- 3 activity. In basal ganglia of $\mathrm{Vps} 13 \mathrm{a}^{-/-}$ mice, Caspase- 3 activity was increased compared to wildtype animals (Additional file 1: Fig. S5D). It is of note that increased Caspase-3 activity has been also reported in brains from PD patients $[4,19]$. In $\mathrm{Vps} 13 \mathrm{a}^{-1-}$ mice, the perturbation of autophagy resulted in accumulation of polyubiquitinated proteins in basal ganglia compared to wild-type animals, further supporting the impairment of autophagy in $\mathrm{Vps}_{13 \mathrm{a}^{-/-}}$mice (Additional file 1: Fig. S5E).

\section{Vps $13 \mathrm{a}^{-I-} \mathrm{Lyn}^{-I-}$ mice show reduced acanthocytes, amelioration of autophagy and decreased activity of NF-kB p65, linked to neuroinflammation}

To further explore the role of Lyn in Vps13a ${ }^{-1-}$ mice, we generated a Vps13a ${ }^{-/} \mathrm{Lyn}^{-1-}$ double knockout mouse (Fig. 3 and Additional file 1: Fig. S6, S7). Since $\mathrm{Lyn}^{-1-}$ mice have been previously characterized and little role for Lyn kinase has been documented on primary neuronal functions $[17,18]$, we focused on the comparison between $\mathrm{Vps} \mathrm{a}^{-1-}$ and $\mathrm{Vps} 13 \mathrm{a}^{-1-} \mathrm{Lyn}^{-1-}$ mice. In addition, the hematologic phenotype of $\mathrm{Lyn}^{-/-}$mice of age less than 15 months is similar to that of wild-type animals (Table S2) $[25,29]$. In 12 months-old Vps13a- ${ }^{-1-} \mathrm{Lyn}^{-1-}$ mice, we observed significantly reduced acanthocyte numbers compared to either $V p s 13 a^{-/-}$or to $V p s 13 a^{-/} L y n^{-/+}$mice. This finding was accompanied by (1) disappearance of the dense red cell fraction; (2) the reduction in HDW and (3) the reduction of red cell osmotic fragility in $\mathrm{Vps} 13 \mathrm{a}^{-/}$ $\mathrm{Lyn}^{-/}$mice compared to both $\mathrm{Vps} 13 \mathrm{a}^{-/-}$and $\mathrm{Vps} 13 \mathrm{a}^{-1-}$ $\mathrm{Lyn}^{-1+}$ mice (Fig. 3a, b, Additional file 1: Fig. S6A-B). $V p s 13 a^{-/-}$mice genetically deficient in Lyn also exhibited normalization of the red cell content of autophagyrelated proteins as compared to their elevated contents in $V p s 13 a^{-1-}$ mouse erythrocytes (Fig. 3c). In isolated basal ganglia from $\mathrm{Vps} 13 \mathrm{a}^{-1-} \mathrm{Lyn}^{-1-}$ mice, we found a slight but significant increase in beclin-1 and a marked reduction in accumulation of Vps34 and p62, supporting the dysregulated autophagy in mice lacking chorein by the incremental absence of Lyn (Fig. 3d). Indeed, we further observed significantly reduced accumulation of polyubiquitinated proteins in the basal ganglia from $\mathrm{Vps} 13 \mathrm{a}^{-1-} \mathrm{Lyn}^{-1-}$ mice compared to $\mathrm{Vps} 1 \mathrm{a}^{-/-}$animals (Fig. 3e). This was associated with reduced NF-kB p65 activation, suggesting a

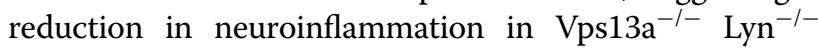
mice (Fig. 3f). Collectively these data support a key role of Lyn in disease mechanism of ChAc.

\section{Proteomic analyses of $\mathrm{Vps} 13 \mathrm{a}^{-/-}$mouse basal ganglia revealed abnormal proteostasis and accumulation of $\gamma$-synuclein}

To understand the abnormal proteostasis in the basal ganglia of $\mathrm{Vps}_{13 \mathrm{a}^{-1-}}$ mice, we carried out proteomic analysis of $\mathrm{Vps} 13 \mathrm{a}^{-/-}$mouse basal ganglia, using a label-free differential proteomic analysis based on Spectral Counts quantification, using Rsc method [75]. Among 3351 total identified proteins, 143 were selected as statistically significant changeable of which 69 were downregulated and 74 were upregulated compared to the basal ganglia of wild-type animals (Fig. 4a). Among the up-regulated proteins, we found of interest the following proteins for our model: (1) $\gamma$-Synuclein, member of the synuclein family; and (2) Synaptotagmins, which are involved in regulation of synaptic vesicle exocytosis; and (3) Syntaxin-1, involved in synaptic transmission $[6,30,47]$. We confirmed the increased expression of $\gamma$-Synuclein and synaptotagmin in isolated basal ganglia from 12- and 18- months old $\mathrm{Vps} 13 \mathrm{a}^{-/-}$mice compared to wild-type animals (Fig. 4b). The accumulation of $\gamma$-synuclein was also confirmed by 


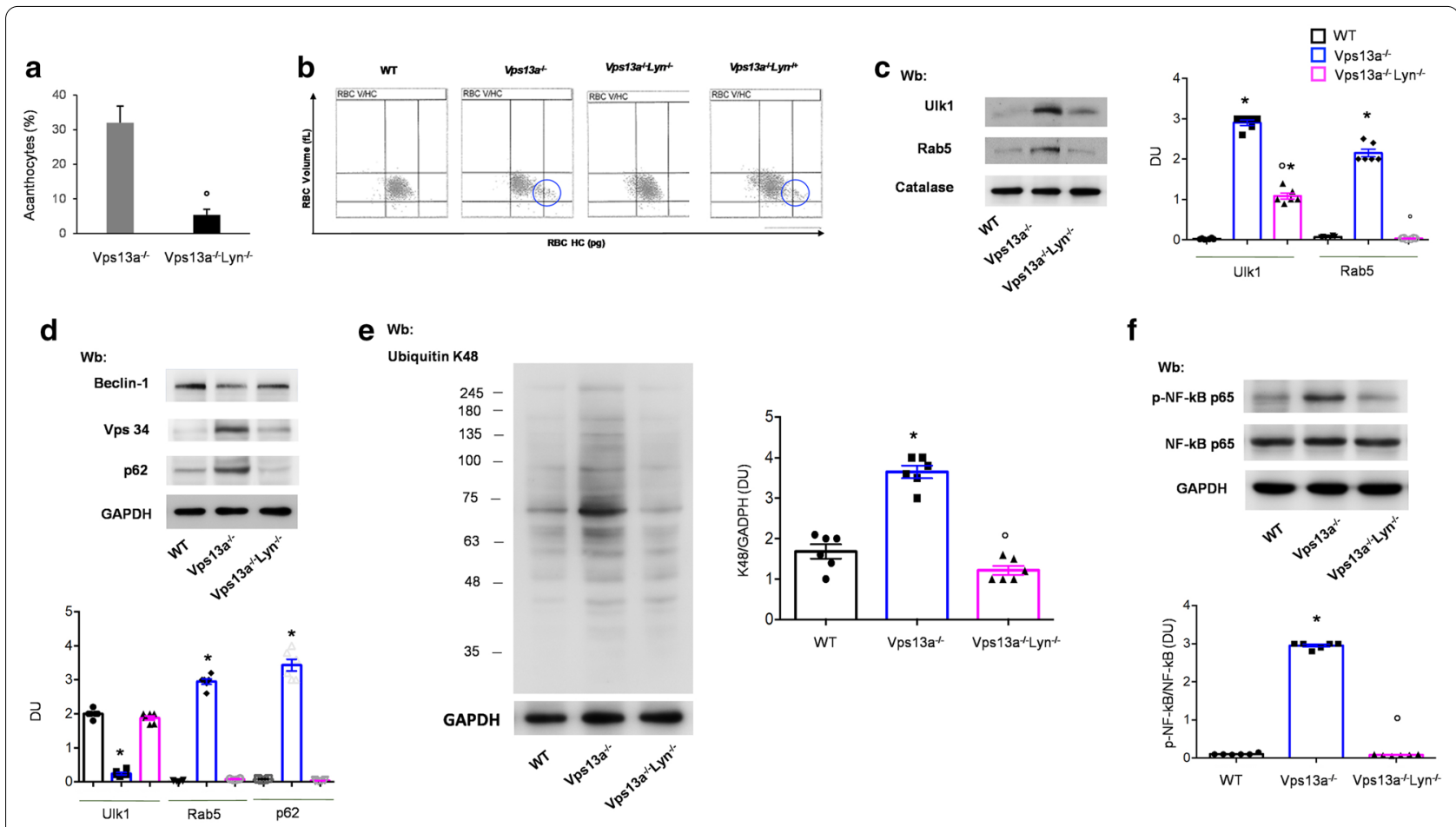

Fig. $3 \mathrm{Vps} 13^{-/-} \mathrm{Lyn}^{-/-}$mice show amelioration of hematologic phenotype and improvement of autophagy and neuroinflammation in basal ganglia. a Quantitation of acanthocytes by brightfield microscopic analysis of peripheral blood smears from $V p s 13 a^{-1-}$ and $V p s 13 a^{-1-} L_{y n}{ }^{-/}$mice. Data from 50 visual fields was collected by two blinded researchers. Results are means \pm SEM $n=6 ;{ }^{\circ} p<0.002$ versus Vps $13 a^{-1-}$ by t-test $\mathbf{b}$ Left panel. Red cell distribution histograms generated for red blood cell volume (RBC Volume) and cell haemoglobin concentration (RBC-HC) of RBCs from wild-type (WT) control, Vps $13 a^{-1-}$, Vps $13 a^{-/-} \mathrm{Lyn}^{-1-}$ and $\mathrm{Vps} 13 \mathrm{a}^{-/-} \mathrm{Lyn}^{-/+}$mice. One representative experiment of six with similar results is shown. The blue circle indicates the presence of a subpopulation of dense red cells containing acanthocytes, as described in human patients (Lupo et al. [42]). c Western blot (Wb) analysis of Ulk1 (Atg1) and Rab 5 from red cell cytosolic fractions of wild-type (WT), Vps $13 a^{-/-}$and $V p s 13 a^{-/-}$Lyn ${ }^{-/-}$mice. Catalase was used as protein loading control. Densitometric analyses of the immunoblot bands similar to those shown are presented at right. Data are means \pm SEM ( $n=6 ;{ }^{*} P<0.02 \mathrm{vs}$. WT; ${ }^{\circ} P<0.05 \mathrm{vs}$. Vps $13 a^{-/-}$by two-way-ANOVA/Bonferroni's multiple comparison test). $\mathbf{d}$ Western blot (Wb) analysis of Beclin-1, Vps34 and p62 in isolated basal ganglia of wild-type (WT), Vps $13 a^{-/-}$and $V p s 13 a^{-/-} \mathrm{Lyn}^{-/-}$mice. GAPDH served as protein loading control. Densitometric analyses of the immunoblot bands similar to those shown are presented at right. Data are means $\pm S E M(n=6$; ${ }^{*} p<0.02$ vs. WT; ${ }^{\circ} p<0.02$ compared to Vps $13 a^{-/-}$mice by two-way-ANOVA/Bonferroni's multiple comparison test). e Western blot (Wb) analysis of K48-ubiquitinated proteins in basal ganglia isolated from wild-type (WT), Vps $13 a^{-/-}$and $\mathrm{Vps} 13 \mathrm{a}^{-/-} \mathrm{Lyn}^{-/-}$mice. GAPDH served as protein loading control. Densitometric analyses of the immunoblot bands similar to those shown are presented at right. Data are means $\pm S E M(n=6$; ${ }^{*} p<0.02$ Vs. WT; ${ }^{\circ} p<0.02$ compared to Vps $13 a^{-/-}$mice by two-way-ANOVA/Bonferroni's multiple comparison test). $\mathbf{f}$ Western blot (Wb) analysis of phospho-NF-kB p65 (P-NF-kB), NF-kB in isolated basal ganglia of wild-type (WT), Vps13a ${ }^{-/-}$and Vps $13 a^{-/-}$Lyn $^{-/-}$mice. GAPDH served as protein loading control. Densitometric analyses of the immunoblot bands similar to those shown are presented at right. Data are means $\pm S E M(n=6$; ${ }^{*} p<0.02$ vs. WT; ${ }^{\circ} p<0.02$ compared to Vps $13 a^{-/-}$mice by two-way-ANOVA/Bonferroni's multiple comparison test)

immunofluorescence microscopy (Fig. 4b, lower panel). The increased expression of $\gamma$-synuclein in basal ganglia from $\mathrm{Vps}_{13 \mathrm{a}^{-1-}}$ mice is of specific note since mice genetically over-expressing $\gamma$-synuclein display an agedependent neurodegeneration, abnormal psycho-emotional status and motor deficiency [47]. Increased levels of $\gamma$-synuclein have been reported in cerebrospinal fluid in Alzheimer disease (AD) patients, in individuals with Creutzfeld-Jakob disease [48], and may contribute to the pathogenesis of amyotrophic lateral sclerosis (ALS) [52]. We then asked whether the increase cellular levels of $\gamma$-synuclein might be associated with the accumulation of other neurotoxic proteins such as neuronal microtubule-associated protein tau, which organizes into pathogenic fibrils in phosphorylated form. We analyzed the Tau phospho-epitopes At8 and At180, which are reported to have functional importance in the neurodegeneration of Alzheimer's disease [33]. In basal ganglia from $\mathrm{Vps} 13 \mathrm{a}^{-/-}$mice, we observed increased levels of At8 and At180 phosphorylated tau compared to wild-type animals (Fig. 4c). The accumulation of phosphorylated At8 and At180 tau protein has been previously linked with Lyn activity in the context of AD [18]: Remarkably, neither $\gamma$-synuclein nor tau 


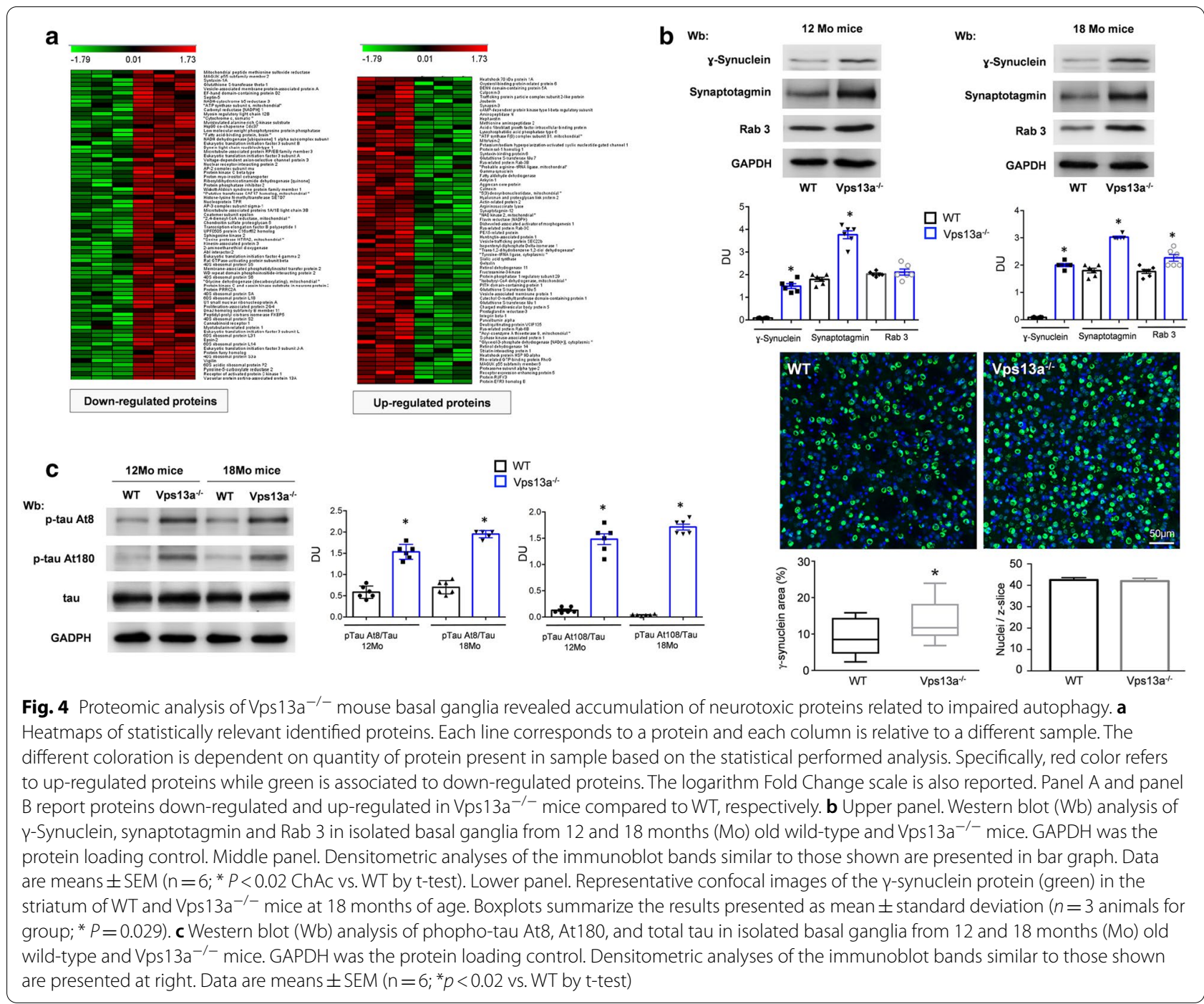

phospho-epitopes At8 and 180 accumulated in isolated basal ganglia from $\mathrm{Vps}_{13 \mathrm{a}^{-/-}} \mathrm{Lyn}^{-/-}$mice (Additional file 1: Fig. S7B-C). Taken together our evidence suggests ChAc as a novel disorder of proteostasis related to impaired autophagy with accumulation of neurotoxic proteins, supporting the rational to target active Lyn as a novel therapeutic option for ChAc.

\section{Dasatinib ameliorates hematologic but not neurologic disease markers in $\mathrm{Vps} 13 \mathrm{a}^{-/-}$mice}

Since we tested dasatinib in our previous in vitro studies, we administrated dasatinib $(50 \mathrm{mg} / \mathrm{kg}$ once a day for 4 weeks) to 12 months-old Vps13a $\mathrm{a}^{-1-}$ mice. Dasatinibtreated $\mathrm{Vps}_{13 \mathrm{a}^{-1-}}$ mice developed mild anemia associated with a significant reduction in reticulocyte count ( $\mathrm{Hb}$ vehicle: $14.6 \pm 0.8$ vs. $\mathrm{Hb}$ dasatinib: $10.3 \pm 1.5 \mathrm{~g} /$ $\mathrm{dL} ; \mathrm{n}=8 ; p<0.02$; retic vehicle $390 \pm 62$ cell $/ \mu \mathrm{L}$ vs. retic dasatinib: $201 \pm 84$ cell $/ \mu \mathrm{L} \quad \mathrm{n}=6 ; p<0.05)$. In
Vps13a ${ }^{-1-}$ mouse RBCs, dasatinib markedly reduced the amount of active Lyn and improved autophagy as supported by the reduction of Ulk1 accumulation compared to vehicle treated animals (Additional file 1: Fig. S8A, B). However, basal ganglia of dasatinib-treated Vps13a ${ }^{-1-}$ mice revealed no major difference in accumulation of active Lyn nor in levels of beclin-1 or beclin-1 related proteins such as Vps34 or Rab 5, suggesting a lacking effect of dasatinib in the central nervous system (Additional file 1: Fig. S8C, D). Mass spectrometric analyses with detection limit of $0.01 \mathrm{pg} / \mu \mathrm{l}$ detected no dasatinib in basal ganglia (Additional file 1: Fig. S9, Table S3). We therefore reviewed the literature on Lyn inhibitors that have been previously reported to better cross the BBB $[12,21,28,49,67]$. We focused on nilotinib, a secondgeneration TKI targeting Lyn, which has been previously shown to ameliorate mouse model phenotypes of PD and 


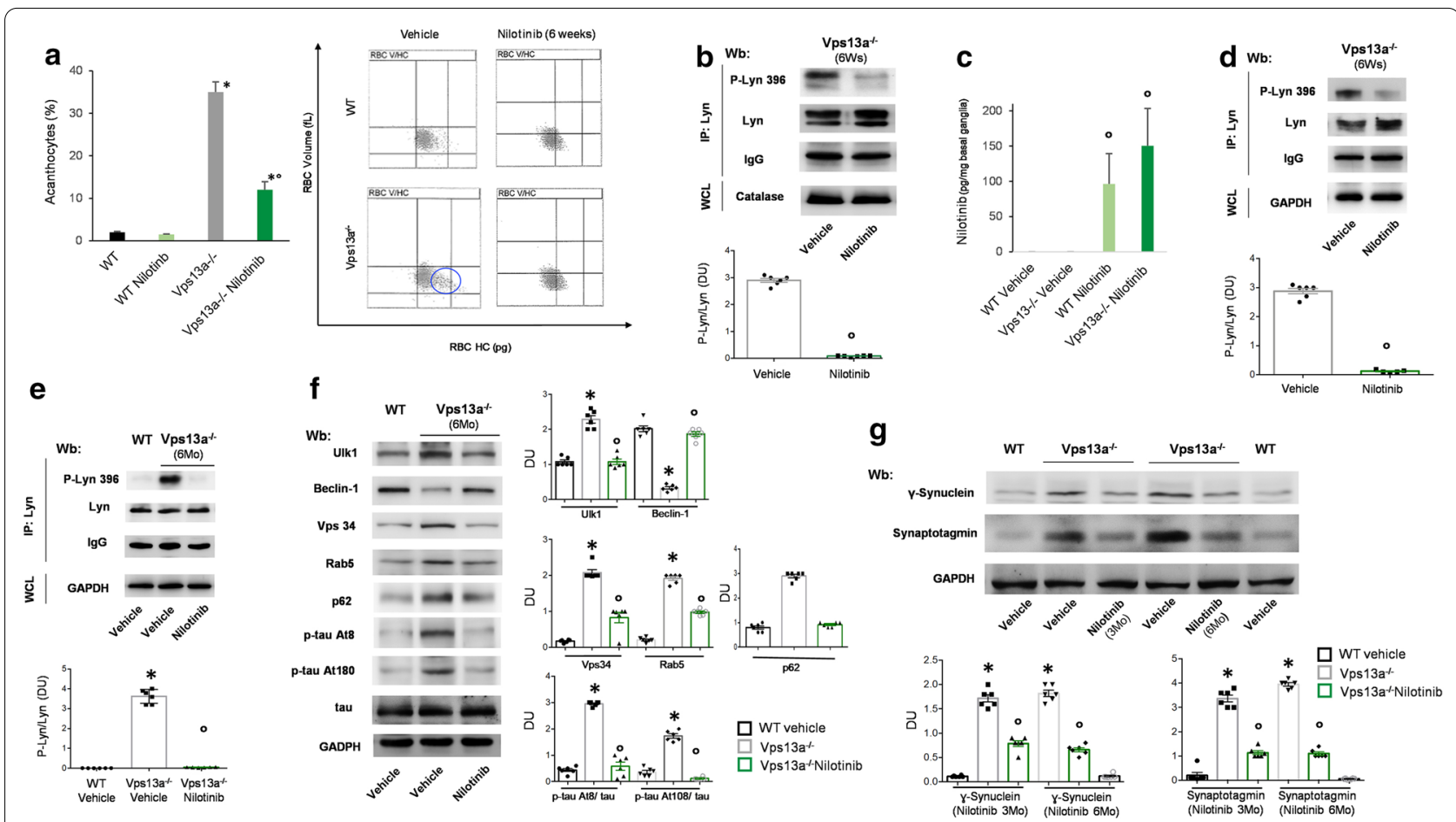

Fig. 5 Nilotinib ameliorates Vps $13 a^{-1-}$ mouse red cell features and its passage into brain across the BBB prevents Lyn activation and improves autophagy. a Left panel. Quantitation of acanthocytes by brightfield microscopic analysis on Vps $13 \mathrm{a}^{-1-}$ and $\mathrm{Vps} 13 \mathrm{a}^{-/-}$mice treated with nilotinib ( $25 \mathrm{mg} / \mathrm{kg} / \mathrm{d}$ for 6 weeks). Data from 50 visual fields was collected by two blinded researchers. Results are means $\pm S E M n=6$; ${ }^{*} P<0.05$ versus WT; ${ }^{\circ} P<0.05$ versus vehicle treated Vps13a ${ }^{-/-}$by 2-way ANOVA with Bonferroni correction for multiple comparison. Right panel. Red cell distribution histograms generated for red blood cell volume (RBC Volume) and cell hemoglobin concentration (RBC-HC) of RBCs from wild-type (WT) control, $\mathrm{Vps} 13 \mathrm{a}^{-1-}$ mice treated with nilotinib ( $25 \mathrm{mg} / \mathrm{kg} / \mathrm{d}$ for 6 weeks). One experiment representative of six others with similar result is shown. The blue circle indicates the presence of a subpopulation of dense red cells, containing acanthocytes as described in human patients (see also Lupo et al. [42]). b Total Lyn was immunoprecipitated from red cell cytosol fractions of $\mathrm{Vps} 13 \mathrm{a}^{-/-}$mice treated with vehicle or with nilotinib ( $25 \mathrm{mg} / \mathrm{kg} / \mathrm{d}$ for 6 weeks (6Ws)) and detected with antibody against active Lyn (phospho-Lyn 396) or antibody against total Lyn (Wb: Western-blot). The experiment shown is representative of 6 experiments. IgG is used as loading control as catalase in whole cell lysate (WCL). Lower panel. Densitometric analysis of the immunoblots; means \pm SEM $(n=6 ; P<0.05$ vs. WT by t-test). c Quantification of nilotinib in isolated basal ganglia from wild-type (WT) and $\mathrm{Vps} 13 \mathrm{a}^{-/-}$mice treated either with vehicle or nilotinib. Data are means $\pm \mathrm{SD}\left(\mathrm{n}=6 ;{ }^{\circ} \mathrm{P}<0.05\right.$ vs. vehicle treated Vps $13 \mathrm{a}^{-/-}$by $2-\mathrm{way}$ ANOVA for multiple comparison). $\mathbf{d}$ Total Lyn was immunoprecipitated from basal ganglia of $\mathrm{Vps} 13 \mathrm{a}^{-1-}$ mice treated with vehicle or with nilotinib (25 mg/ $\mathrm{kg} / \mathrm{d}$ for 6 weeks $(6 \mathrm{Ws})$ ). The experiment shown is representative of 6 experiments, each from an individual Vps $13 \mathrm{a}^{-1-}$ mouse and each with similar results. IgG and catalase are used as loading control. WCL: whole cell lysate. Lower panel. Densitometric analysis of the immunoblots; means \pm SEM $\left(n=6 ;^{\circ} P<0.05\right.$ vs. WT by t-test). e Total Lyn was immunoprecipitated from basal ganglia of wild-type and Vps $13 a^{-/-}$mice treated with vehicle or with nilotinib (25 mg/kg/d for 6 months (6Mo), 12 months old mice) and detected with antibody against active Lyn (phospho-Lyn 396) or antibody against total Lyn (Wb: Western-blot). The experiment shown is representative of 6 experiments, each from an individual Vps13a ${ }^{-1-}$ mouse and each with similar results. IgG is shown as loading control as well as GAPDH in whole cell lysate (WCL). Lower panel. Densitometric analysis of the immunoblots; means \pm SEM $\left(n=6{ }^{*} P<0.05\right.$ vs. WT; ${ }^{\circ} P<0.05$ vs. vehicle treated Vps $13 a^{-/-}$by 2 -way ANOVA with Bonferroni correction for multiple comparison). f Western blot (Wb) analysis of Ulk1 (Atg1), Beclin-1, Vps34, Rab5, p62, phospho-tau At8, and At180 and total tau in isolated basal ganglia from 18 months old wild-type, and $V p s 13 a^{-/-}$mice treated with either vehicle or nilotinib ( $25 \mathrm{mg} / \mathrm{kg} / \mathrm{d}$ for 6 months (6Mo)). GAPDH was used as loading control (See Additional file 1: Fig. $14 \mathrm{~S}$ for data on nilotinib treated 12 months-old mice). Right panel. Densitometric analyses of the immunoblot bands similar to those shown are presented at right. Data are means $\pm S E M\left(n=6 ;{ }^{*} P<0.05\right.$ Vs. WT; ${ }^{\circ} P<0.05$ vs. vehicle treated

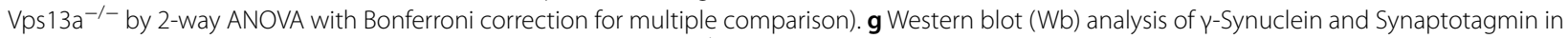

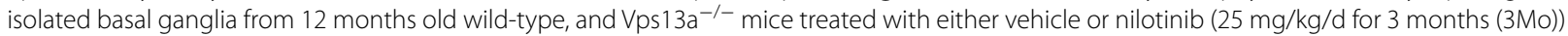
and 18 months old wild-type, and Vps13a ${ }^{-/-}$mice treated with either vehicle or nilotinib (25 mg/kg/d for 6 months (6Mo)). GAPDH was used as loading control. Lower panel. Densitometric analyses of the immunoblot bands similar to those shown are presented. Data are means $\pm S E M(n=6$; ${ }^{*} P<0.05$ vs. WT; ${ }^{\circ} P<0.05$ vs. vehicle treated Vps $13 a^{-1-}$ by 2-way ANOVA with Bonferroni correction for multiple comparison) 
AD by improving autophagy [12, 21, 28], and has tested in 6 months phase II clinical trial in PD patients $[49,62]$.

\section{Nilotinib reduces acanthocytosis, improves autophagy and neuroinflammation in basal ganglia from $\mathrm{Vps} 13 \mathrm{a}^{-/-}$ mice}

In $\mathrm{Vps} 13 \mathrm{a}^{-/-}$mice, nilotinib (1) markedly reduced acanthocytosis and dense red cell fraction (Fig. 5a, Additional file 1: Fig. S10A); (2) prevented the accumulation of active Lyn in $\mathrm{Vps}_{13 \mathrm{a}^{-1-}}$ mouse RBCs (Fig. 5b); and (3) normalized RBC autophagy related proteins Ulk1 and Atg7 accumulation (Additional file 1: Fig. S10B). Nilotinib was detected by LC-MS/MS spectrometric analysis in basal ganglia from WT and $V p s 13 a^{-/-}$mice (Fig. 5c, Additional file 1: Fig. S10C, Table S4). The presence of nilotinib in $V p s 13 a^{-/-}$mouse basal ganglia was associated with markedly reduced basal ganglia accumulation of active Lyn after nilotinib treatment for 6 weeks or for 6 months (Fig. 5d, e). Accumulation of the key autophagyrelated proteins Ulk1, Vps34, Rab5 and p62 were also reduced in basal ganglia of mice treated with nilotinib for either 6 weeks or 6 months (Fig. 5f, Additional file 1: Fig. S10D). Noteworthy, increased $V p s 13 a^{-1-}$ mouse basal ganglia beclin-1 levels were noted only after 6 months' nilotinib treatment (Fig. 5f, Additional file 1: Fig. S10D). Accumulation of phospho-tau At8 and At180 (Fig. 5f, Additional file 1: Fig. S10E), $\gamma$-synuclein and synaptotagmin (Fig. 5g) were prevented by nilotinib treatment in basal ganglia from $V p s 13 a^{-/-}$mice. Finally, we evaluated the impact of long-term treatment (3-6 months) on neuroinflammation in $\mathrm{Vps} 13 \mathrm{a}^{-/-}$mice. As shown in Fig. 6a, $\mathrm{b}$ and Additional file 1: Fig. S11, we observed a significant reduction in microglia associated with decreased activated NF-kB p65 in both cortex and basal ganglia. Taken

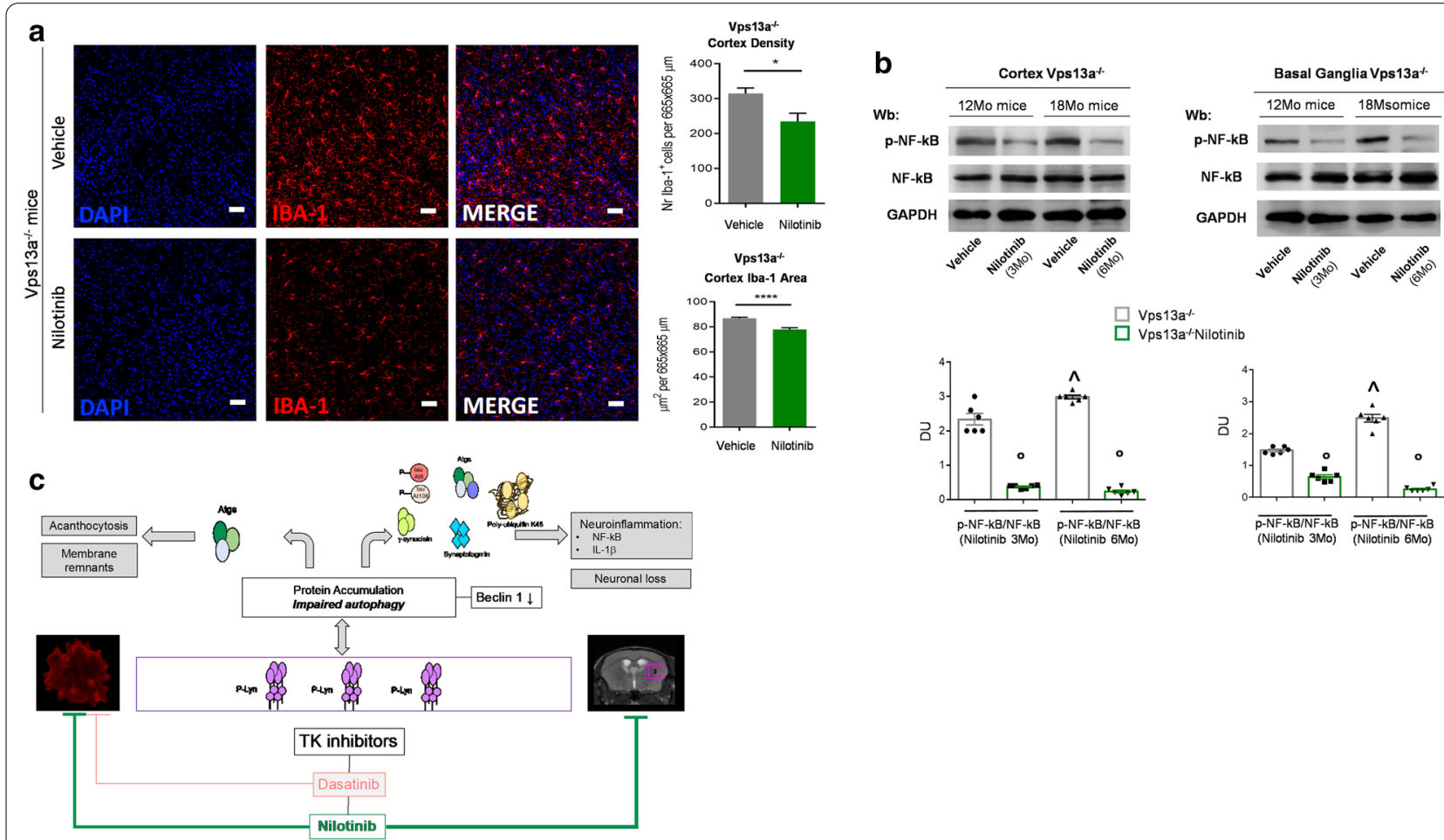

Fig. 6 Nilotinib decreases neuroinflammation in Vps13a-l- mice. a Representative images of Iba-1 positive microglia cells in cortex of Vps $13 a^{-/-}$ mice treated with vehicle or with nilotinib (25 mg/kg/d for 6 months) (Microglia in red, nuclei in blue). Scale bar:50 mm. Quantitative analyses show significant differences in microglial density and activation in the cortex of $\mathrm{Vps} 13 \mathrm{a}^{-/-}$vehicle compared to treated mice. Results are expressed as mean \pm SEM $\left({ }^{*} P<0.05 ;{ }^{* * *} P<0.0001\right.$; Unpaired t-test). b Western blot (Wb) analysis of phospho-NF-kB p65 and NF-kB p65 in the cortex (left panel) and in isolated basal ganglia (right panel) from 12 and 18 months (Mo) old wild-type mice and Vps13a ${ }^{-1-}$ animals treated with vehicle or with nilotinib $(25 \mathrm{mg} / \mathrm{kg} / \mathrm{d}$ for 3 months (3Mo) and 6 months (6Mo) respectively). GAPDH was the protein loading control. Lower panel. Densitometric analyses of the immunoblot bands similar to those shown are presented. Data are means \pm SEM $\left(n=6 ; \wedge P<0.05\right.$ vs. 12 months old mice; ${ }^{\circ} P<0.05$ vs. vehicle treated Vps13a $a^{-/-}$by 2-way ANOVA with Bonferroni correction for multiple comparison). c Mice genetically lacking chorein (Vps13a ${ }^{-/-}$) display phenotype similar to patients with chorea-acanthocytosis (ChAc). We show protein accumulation and impaired autophagy in both red cells and basal ganglia from Vps13a $a^{-/-}$mice. This is associated with neuronal loss, neuroinflammation and generation of circulating acanthocytes. Tyrosine kinase inhibitors (TKI) targeting Lyn kinase have been tested in Vps $13 a^{-1-}$ mice. Nilotinib but not dasatinib reduces protein accumulation and ameliorates autophagy with reduction in neuronal loss and neuroinflammation as well as in circulating acanthocytes. Atgs: autophagy related proteins 
together, our data support the accumulation of active Lyn and impaired autophagy as possible therapeutic targets for clinical intervention in ChAc. We demonstrated that nilotinib crosses the BBB, improves autophagy and reduces neuroinflammation in a mouse model for ChAc.

\section{Discussion}

ChAc is a rare, progressive, multisystem neurodegenerative disease of young adulthood with no available treatment to halt or retard its devastating progression out. The identification of new therapeutic option(s) targeting disease mechanism(s) represents an urgent unmet need in ChAc. We first characterized $V p s 13 a^{-/-}$mice in order to advance understanding of ChAc and to search for additional drug targets and novel drug candidates. $\mathrm{Vps13a}^{-/-}$mice display (1) acanthocytes; (2) signs of both hyper- and hypokinetic movement disorders; (3) accumulation of active Lyn and of autophagy-related proteins in RBCs; and (4) RBC retention of remnants of double membrane and multivesicular bodies. Abnormalities in motor behavior observed in $\mathrm{Vps}_{13 \mathrm{a}^{-1-}}$ mice correlate with the movement disorders, specifically dystonia, seen in ChAc patients [50, 70]. Indeed, the neurologic phenotype of $V p s 13 a^{-/-}$mice resembles that of another mouse model for ChAc carrying a deletion of exons 60-61. [66]. In isolated basal ganglia of $\mathrm{Vps} 13 \mathrm{a}^{-/-}$mice, we found signs of neurodegeneration associated with (1) accumulation of Lyn, stabilized in high molecular weight complexes; (2) accumulation of autophagy related proteins; and (3) reduction in expression of beclin-1, a key initiator of autophagy, due to increased caspase 3 activity. Normalization of phenotypes in the $\mathrm{Vps} 13 \mathrm{a}^{-/-} \mathrm{Lyn}^{-1-}$ double knock out model substantiates the central role of accumulation of active Lyn in the pathophysiology of ChAc. Lyn has been previously reported to contribute to varied neuronal functions throughout the phosphorylation of key substrates such as NMDA or AMPA receptors [16, 41, 59]. In addition, in vitro studies also suggest that active Lyn might reduce or alter exocytosis by phosphorylation of both proteins of synaptic vesicles and actin cytoskeleton [16]. Lyn and Src family kinases have been also shown to participate in autophagy by targeting various autophagy-related proteins such as Ulk1 [36, 37, 42]. However, the accumulation of active Src family kinases might be per se cytotoxic, contributing to impaired autophagy as reported in cancer cells [72, 73] The accumulation of At8- and At180-phosphorylated tau proteins and $\gamma$-synuclein as well as of polyubiquinated proteins in $\mathrm{Vps} 13 \mathrm{a}^{-1-}$ mouse basal ganglia is consistent with abnormal autophagy in the absence of chorein. Our data adds ChAc, for the first time, to the group of classical neurodegenerative proteinopathies such as AD, PD and HD. These three diseases are also characterized by abnormalities in autophagy as well as by reduced beclin-1 [58, 61, 63]. In addition, recent reports of severe neurodegeneration and impairment of autophagy in beclin $1^{-1-}$ mice further links beclin-1-dependent autophagy to neurodegenerative diseases $[45,55,65]$. In particular, the beclin-1-Vps34 complex is critical for autophagosome formation, subsequently involving Atg14 with recruitment of Rab 5 [45, 58]. In Vps13a ${ }^{-1-}$ mice, the absence of chorein results in impairment of beclin-1 pathway with accumulation of Vps34, Atg14 and Rab5, suggesting a perturbation of protein trafficking associated with possible abnormalities in maturation and/or degradation of autophagosomes. This is further supported by the association between chorein with beclin-1 observed in basal ganglia from wild-type mice. Although chorein does not contain a recognized actin-binding motif, it carries a coil-coil binding motif that may be involved in beclin-1 interactions. A complex connection has been reported between beclin-1 and inflammation [24, 46]. In vitro studies show that block of autophagy results in up-regulation of pro-inflammatory cytokines such as IL-1 $\beta[24,46]$. Here, we found neuroinflammation in $\mathrm{Vps}_{13 \mathrm{a}^{-1-}}$ mice associated with activation of NF-kB p65 and increased expression of IL-1 $\beta$ further emphasizing similarities between ChAc and other neurodegenerative disorders characterized by abnormal proteostasis such as $\mathrm{PD}$ or $\mathrm{AD}$ [15]. At this stage we cannot determine whether neuroinflammation is directly involved in the etiology of ChAc or indirectly related to the neurodegenerative processes in the basal ganglia. Although systematic investigation of ChAc neuropathology in human brains is still lacking, preliminary reports on brain from patients with ChAc suggests the presence of microgliosis $[38,39,50]$.

Collectively these findings led us to test in our mouse ChAc model a Lyn kinase inhibitor that crosses the BBB more easily than dasatinib. Nilotinib beneficially impacts ChAc mouse hematological phenotype and improves ChAc RBC features. Furthermore, nilotinib was detected in basal ganglia from $\mathrm{Vps} 13 \mathrm{a}^{-/-}$mice resulting in improvement of autophagy with reduction of active Lyn and accumulation of autophagy related proteins. $V p s 13 a^{-/-}$mice treated long-term with nilotinib exhibited increased levels of basal ganglia beclin-1, associated with reduced microglia density and reduced active NF-kB p65. These data further supported the link between beclin-1 dependent autophagy and inflammation in ChAc mice.

In conclusion, our data show for the first time that the pathogenesis of ChAc is linked to perturbation of beclin-1 pathway, resulting in impaired autophagy with accumulation of active Lyn and classic neurotoxic proteins such as $\gamma$-synuclein or phospho-tau 
At8 and At180. Abnormal autophagy contributes to NF- $k B$ activation and expression of pro-inflammatory cytokines, such as Il-1b, in combination with microglia activation, sustaining a neuroinflammatory environment in ChAc as in other neurodegenerative disorders such as PD or AD. Our data prove active Lyn to be a key regulator of neurodegeneration in ChAc, thus generating a rationale to consider TKIs targeting Lyn per se as possible and safe novel therapeutic approach for ChAc patients (Fig. 6c). Our results propose BBBpermeable Lyn kinase inhibitors such as nilotinib as first-line treatment options for patients suffering from ChAc. As nilotinib is already in clinical use for treatment of other diseases [21], larger-scale studies of nilotinib for treatment of ChAc should be eligible for accelerated approval. Our data support the proposal to repurpose nilotinib as new therapeutic option for ChAc.

\section{Supplementary Information}

The online version contains supplementary material available at https://doi. org/10.1186/s40478-021-01181-y.

\section{Additional file 1.}

\section{Acknowledgements}

We thank Dr. Francesca Lupo (University of Verona), Dr. Manuela Medelin (University of Verona) for generation of preliminary data, analysis of some immunofluorescence images and fruitful discussion, respectively. We would like to thank CIRSAL, LURM and CPT (University of Verona) for technical support.

\section{Authors' contributions}

K.P. A.H. and L.D.F. designed all of the experiments. E.C.P. and G.C. contributed to the obtainment of neuropathology and behavior data. ET, PD generated mice lines, B.K., A.H. and L.D.F. supervised the project, K.P., A.H. and L.D.F. wrote the manuscript and all other authors critically revised the manuscript. K.P., A.H. and L.D.F.: Research project: Conception, Organization, Execution; Statistical Analysis: Design/Execution; Manuscript: Writing of the first draft. E.F. and A.M.: Research project: Conception, Organization, Execution. H.G.: Research project: Organization/Execution; Statistical Analysis: Design, Execution, Review and Critique; Manuscript: Review and Critique. G.C. and P.F.F.: Research project: Conception; Statistical Analysis: Design, Execution, Review and Critique; Manuscript: Writing of the first draft. E.C.P., F.D.G., A.I., F.C., F.G., I.A. and E.L. Research project: Execution; Statistical Analysis: Execution. P.D.: Research project: Conception, Organization, Execution; Manuscript: Writing of the first draft. E.T. and P.P.: Research project: Conception; Manuscript: Writing of the first draft. A.A., M.M. and E.T:: Research project: Conception, Organization; Statistical Analysis: Design, Execution, Review and Critique; Manuscript: Writing of the first draft. SLALP, KA: Research project: Execution; Statistical Analysis: Execution; Manuscript: Review and Critique. T.Z.: Manuscript: Review and Critique. R.O.: Research project: Conception/Organization; Manuscript: Review and Critique. F.L.: Research project: Organization; Manuscript: Review and Critique. A.M.B.: Research project: Conception; Statistical Analysis: Review and Critique; Manuscript: Writing of the first draft. E.T.: Research project: Conception, Organization, Execution; Statistical Analysis: Execution. Aio, M.B., A.D. and R.H.W.: Manuscript: Writing of the first draft. M.B.: Research project: Conception, Organization, Execution; Statistical Analysis: Review and Critique; Manuscript: Writing of the first draft. A.S.: Research project: Execution. All authors read and approved the final manuscript.

\section{Funding}

This study was supported in part by the Centre for Regenerative Therapies Dresden (CRTD), the German Center for Neurodegenerative Diseases (DZNE), research site Dresden, the Helmholtz Virtual Institute (VH-VI-510), by the Advocacy for Neuroacanthocytosis Patients (AH, LDF), by the Else Kröner Clinician Scientist Program (TU Dresden, Germany) and the Rostock Academy for Clinician Scientists (RACS, University of Rostock, Germany) (KP), the "Hermann und Lilly Schilling-Stiftung für medizinische Forschung im Stifterverband" (AH). The work was also supported in part by the European Research Council (ERC) Advanced Grant Immunoalzheimer \#695714 (to GC) and FUR-UNIVR (LDF).

\section{Declarations}

\section{Competing interests}

KP has received funding from the Else Kröner Clinician Scientist Program (TU Dresden, Germany) and the MeDDrive grant of the Technische Universität Dresden, and the Rostock Academy for Clinician Scientists (RACS, University of Rostock, Germany). HG, LP, AM, FL, EF, GC, ECP RO, PFF, PDF, ET, FDG, PP, AA, Al, $F C, M M, F G, E T, A M B, E T, I A, A l, M B, E L, A S, M B, A D$ AND RHW none. KA received honoraria for presentation and consulting service from Biogen Idec, Merck, Sanofi and Roche. TZ received honoraria for presentation and consulting service from Biogen, Bayer, Celgene, Novartis, Roche, Sanofi, Teva. He received additional financial support for research activities from BAT, Biogen, Novartis, Roche, Teva, and Sanofi Aventis. AH has received funding from the Federal Ministry of Education and Research (BMBF), the Helmholtz-Association, the Schilling-Stiftung, the "Innovationsfond des Gemeinsamen Bundenausschusses". He has received honoraria for presentations, advisory boards, consultations from BIOGEN and Desitin. He has received royalties from Elsevier Press. He serves as an editorial board member of BMC Neurology. SLA has received research funding from the US DoD and Quest Diagnostics. He has received consultation fees from the Broad Institute, the Medical University of Vienna, and Quest Diagnostics. LDF has received research funding by Agios.

\section{Author details}

"Translational Neurodegeneration Section "Albrecht-Kossel", Department of Neurology, University Medical Center Rostock, University of Rostock, Gehlsheimer Straße 20, 18147 Rostock, Germany. ${ }^{2}$ Department of Medicine, University of Verona, Policlinico GB Rossi, P.Le L. Scuro, 10, 37134 Verona, Italy. ${ }^{3}$ Department of Neuroscience, Biomedicine and Movement Sciences, University of Verona, Verona, Italy. ${ }^{4}$ Department of Biotecnologie Molecolari E Scienze Per La Salute, University of Torino, Turin, Italy. ${ }^{5}$ Department of Chemical Sciences, University Federico II of Napoli, Naples, Italy. ${ }^{6}$ Molecular Imaging Center - Department of Molecular Biotechnology and Health Sciences, University of Torino, Turin, Italy. ${ }^{7}$ Division of Nephrology, Beth Israel Deaconess Medical Center, Harvard Medical School, Boston, MA, USA. ${ }^{8}$ Department of Physiology I, Eberhard Karl University, Tübingen, Germany. ${ }^{9}$ Transfusion Medicine, Eberhard Karl University, Tübingen, Germany. ${ }^{10}$ Department of Neurology, University Hospital Carl Gustav Carus, Technische Universität Dresden, Dresden, Germany. ${ }^{11}$ Medical Department I, University Hospital Carl Gustav Carus, Technische Universität Dresden, Dresden, Germany. ${ }^{12}$ Department of Molecular Medicine, University of Padua, Padua, Italy. ${ }^{13}$ Department of Molecular Medicine and Medical Biotechnology, University of Naples Federico II, Naples, Italy. ${ }^{14}$ Department of Neurology, James J. Peters Veterans Affairs Medical Center, Bronx, NY, USA. ${ }^{15}$ Department of Neurology, Ludwig Maximilians University of Munich, Munich, Germany. ${ }^{16}$ Department of Neurology, Icahn School of Medicine at Mount Sinai, New York, NY, USA. ${ }^{17}$ Centro Piattaforme Tecnologiche, University of Verona, Verona, Italy. ${ }^{18}$ Center for Transdisciplinary Neurosciences Rostock (CTNR), University Medical Center Rostock, University of Rostock, Rostock, Germany. ${ }^{19}$ Division for Neurodegenerative Diseases,Department of Neurology, Technische Universität Dresden, Dresden, Germany. ${ }^{20}$ Center for Regenerative Therapies Dresden, Dresden, Germany. ${ }^{21}$ CEINGE Biotecnologie Avanzate, Naples, Italy.

Received: 14 February 2021 Accepted: 14 April 2021 Published online: 03 May 2021 


\section{References}

1. Arora A, Bhagat N (2016) Insight into the molecular imaging of Alzheimer's disease. Int J Biomed Imaging 2016:7462014. https://doi.org/10. 1155/2016/7462014

2. Baiguera C, Alghisi M, Pinna A, Bellucci A, De Luca MA, Frau L, Morelli M, Ingrassia R, Benarese M, Porrini V, Pellitteri M, Bertini G, Fabene PF, Sigala S, Spillantini MG, Liou HC, Spano PF, Pizzi M (2012) Late-onset Parkinsonism in NFkappaB/c-Rel-deficient mice. Brain 135:2750-2765. https://doi.org/ 10.1093/brain/aws193

3. Batka RJ, Brown TJ, Mcmillan KP, Meadows RM, Jones KJ, Haulcomb MM (2014) The need for speed in rodent locomotion analyses. Anat Rec (Hoboken) 297:1839-1864. https://doi.org/10.1002/ar.22955

4. Blandini F, Cosentino M, Mangiagalli A, Marino F, Samuele A, Rasini E, Fancellu R, Tassorelli C, Pacchetti C, Martignoni E, Riboldazzi G, Calandrella D, Lecchini S, Frigo G, Nappi G (2004) Modifications of apoptosis-related protein levels in lymphocytes of patients with Parkinson's disease. The effect of dopaminergic treatment. J Neural Transm (Vienna) 111:10171030. https://doi.org/10.1007/s00702-004-0123-1

5. Clark MR, Aminoff MJ, Chiu DT, Kuypers FA, Friend DS (1989) Red cell deformability and lipid composition in two forms of acanthocytosis: enrichment of acanthocytic populations by density gradient centrifugation. J Lab Clin Med 113:469-481

6. Colacurcio DJ, Pensalfini A, Jiang Y, Nixon RA (2018) Dysfunction of autophagy and endosomal-lysosomal pathways: roles in pathogenesis of down syndrome and Alzheimer's disease. Free Radic Biol Med 114:40-51. https://doi.org/10.1016/j.freeradbiomed.2017.10.001

7. Critchley EM, Clark DB, Wikler A (1968) Acanthocytosis and neurological disorder without betalipoproteinemia. Arch Neurol 18:134-140

8. Danek A, Bader B, Velayos-Baeza A, Walker RH (2012) Autosomal recessive transmission of chorea-acanthocytosis confirmed. Acta Neuropathol 123:905-906. https://doi.org/10.1007/s00401-012-0971-y

9. De Franceschi L, Tomelleri C, Matte A, Brunati AM, Bovee-Geurts PH, Bertoldi M, Lasonder E, Tibaldi E, Danek A, Walker RH, Jung HH, Bader B, Siciliano A, Ferru E, Mohandas N, Bosman GJ (2011) Erythrocyte membrane changes of chorea-acanthocytosis are the result of altered Lyn kinase activity. Blood 118:5652-5663. https://doi.org/10.1182/ blood-2011-05-355339

10. Dobson-Stone C, Danek A, Rampoldi L, Hardie RJ, Chalmers RM, Wood NW, Bohlega S, Dotti MT, Federico A, Shizuka M, Tanaka M, Watanabe M, Ikeda Y, Brin M, Goldfarb LG, Karp BI, Mohiddin S, Fananapazir L, Storch A, Fryer AE, Maddison P, Sibon I, Trevisol-Bittencourt PC, Singer C, Caballero IR, Aasly JO, Schmierer K, Dengler R, Hiersemenzel LP, Zeviani M, Meiner V, Lossos A, Johnson S, Mercado FC, Sorrentino G, Dupre N, Rouleau GA, Volkmann J, Arpa J, Lees A, Geraud G, Chouinard S, Nemeth A, Monaco AP (2002) Mutational spectrum of the CHAC gene in patients with chorea-acanthocytosis. Eur J Hum Genet 10:773-781. https://doi.org/10. 1038/sj.ejhg.5200866

11. Duarte JM, Do KQ, Gruetter R (2014) Longitudinal neurochemical modifications in the aging mouse brain measured in vivo by $1 \mathrm{H}$ magnetic resonance spectroscopy. Neurobiol Aging 35:1660-1668. https://doi.org/ 10.1016/j.neurobiolaging.2014.01.135

12. Elkouzi A, Vedam-Mai V, Eisinger RS, Okun MS (2019) Emerging therapies in Parkinson disease: repurposed drugs and new approaches. Nat Rev Neurol 15:204-223. https://doi.org/10.1038/s41582-019-0155-7

13. Estevez-Fraga C, Lopez-Sendon Moreno JL, Martinez-Castrillo JC (2018) Phenomenology and disease progression of chorea-acanthocytosis patients in Spain. Parkinsonism Relat Disord 49:17-21. https://doi.org/10. 1016/j.parkreldis.2017.10.016

14. Gao M, Yang H (2018) VPS13: a lipid transfer protein making contacts at multiple cellular locations. J Cell Biol 217:3322-3324. https://doi.org/10. 1083/jcb.201808151

15. Gelders G, Baekelandt V, Van der Perren A (2018) Linking neuroinflammation and neurodegeneration in Parkinson's disease. J Immunol Res 2018:4784268. https://doi.org/10.1155/2018/4784268

16. Gibb SL, Jeanblanc J, Barak S, Yowell QV, Yaka R, Ron D (2011) Lyn kinase regulates mesolimbic dopamine release: implication for alcohol reward. J Neurosci 31:2180-2187. https://doi.org/10.1523/JNEUROSCI.5540-10. 2011

17. Gwon Y, Kim SH, Kim HT, Kam TI, Park J, Lim B, Cha H, Chang HJ, Hong YR, Jung YK (2019) Amelioration of amyloid beta-FcgammaRIlb neurotoxicity and tau pathologies by targeting LYN. FASEB J Off Publ Fed Am Soc Exp Biol 33:4300-4313. https://doi.org/10.1096/f.201800926R

18. Gwon Y, Kim SH, Kim HT, Kam TI, Park J, Lim B, Cha H, Chang HJ, Hong YR, Jung YK (2019) Amelioration of amyloid $\beta$-FcyRllb neurotoxicity and tau pathologies by targeting LYN. FASEB J 33:4300-4313. https://doi.org/10. 1096/f.201800926R

19. Hartmann A, Hunot S, Michel PP, Muriel MP, Vyas S, Faucheux BA, MouattPrigent A, Turmel H, Srinivasan A, Ruberg M, Evan Gl, Agid Y, Hirsch EC (2000) Caspase-3: a vulnerability factor and final effector in apoptotic death of dopaminergic neurons in Parkinson's disease. Proc Natl Acad Sci USA 97:2875-2880. https://doi.org/10.1073/pnas.040556597

20. Hebron ML, Lonskaya I, Moussa CE (2013) Nilotinib reverses loss of dopamine neurons and improves motor behavior via autophagic degradation of alpha-synuclein in Parkinson's disease models. Hum Mol Genet 22:3315-3328. https://doi.org/10.1093/hmg/ddt192

21. Heffron TP (2016) Small molecule kinase inhibitors for the treatment of brain cancer. J Med Chem 59:10030-10066. https://doi.org/10.1021/acs. jmedchem.6b00618

22. Hermann A, Walker RH (2015) Diagnosis and treatment of chorea syndromes. Curr Neurol Neurosci Rep 15:514. https://doi.org/10.1007/ s11910-014-0514-0

23. Hirsch EC, Hunot S (2009) Neuroinflammation in Parkinson's disease: a target for neuroprotection? Lancet Neurol 8:382-397. https://doi.org/10. 1016/s1474-4422(09)70062-6

24. Houtman J, Freitag K, Gimber N, Schmoranzer J, Heppner FL, Jendrach M (2019) Beclin1-driven autophagy modulates the inflammatory response of microglia via NLRP3. EMBO J. https://doi.org/10.15252/embj.20189 9430

25. Ingley E, McCarthy DJ, Pore JR, Sarna MK, Adenan AS, Wright MJ, Erber W, Tilbrook PA, Klinken SP (2005) Lyn deficiency reduces GATA-1, EKLF and STAT5, and induces extramedullary stress erythropoiesis. Oncogene 24:336-343. https://doi.org/10.1038/sj.onc.1208199

26. Jung HH, Danek A, Walker RH (2011) Neuroacanthocytosis syndromes. Orphanet J Rare Dis 6:68. https://doi.org/10.1186/1750-1172-6-68

27. Kalish BT, Matte A, Andolfo I, lolascon A, Weinberg O, Ghigo A, Cimino J, Siciliano A, Hirsch E, Federti E, Puder M, Brugnara C, De Franceschi L (2015) Dietary $\omega$-3 fatty acids protect against vasculopathy in a transgenic mouse model of sickle cell disease. Haematologica 100:870-880. https://doi.org/10.3324/haematol.2015.124586

28. Karuppagounder SS, Brahmachari S, Lee Y, Dawson VL, Dawson TM, Ko HS (2014) The c-Abl inhibitor, nilotinib, protects dopaminergic neurons in a preclinical animal model of Parkinson's disease. Sci Rep 4:4874. https:// doi.org/10.1038/srep04874

29. Karur VG, Lowell CA, Besmer P, Agosti V, Wojchowski DM (2006) Lyn kinase promotes erythroblast expansion and late-stage development. Blood 108:1524-1532. https://doi.org/10.1182/blood-2005-09-008243

30. Kimura N, Yanagisawa K (2018) Traffic jam hypothesis: Relationship between endocytic dysfunction and Alzheimer's disease. Neurochem Int 119:35-41. https://doi.org/10.1016/j.neuint.2017.07.002

31. Kuhla A, Ruhlmann C, Lindner T, Polei S, Hadlich S, Krause BJ, Vollmar B, Teipel SJ (2017) APPswe/PS1dE9 mice with cortical amyloid pathology show a reduced NAA/Cr ratio without apparent brain atrophy: a MRS and MRI study. Neurolmage Clin 15:581-586. https://doi.org/10.1016/j.nicl. 2017.06.009

32. Kumar N, Leonzino M, Hancock-Cerutti W, Horenkamp FA, Li P, Lees JA, Wheeler H, Reinisch KM, De Camilli P (2018) VPS13A and VPS13C are lipid transport proteins differentially localized at ER contact sites. J Cell Biol 217:3625-3639. https://doi.org/10.1083/jcb.201807019

33. Landrieu I, Smet-Nocca C, Amniai L, Louis JV, Wieruszeski JM, Goris J, Janssens V, Lippens G (2011) Molecular implication of PP2A and Pin 1 in the Alzheimer's disease specific hyperphosphorylation of Tau. PLoS ONE 6:e21521. https://doi.org/10.1371/journal.pone.0021521

34. Lesage S, Drouet V, Majounie E, Deramecourt V, Jacoupy M, Nicolas A, Cormier-Dequaire F, Hassoun SM, Pujol C, Ciura S, Erpapazoglou Z, Usenko T, Maurage CA, Sahbatou M, Liebau S, Ding J, Bilgic B, Emre M, Erginel-Unaltuna N, Guven G, Tison F, Tranchant C, Vidailhet M, Corvol JC, Krack P, Leutenegger AL, Nalls MA, Hernandez DG, Heutink P, Gibbs JR, Hardy J, Wood NW, Gasser T, Durr A, Deleuze JF, Tazir M, Destee A, Lohmann E, Kabashi E, Singleton A, Corti O, Brice A (2016) Loss of VPS13C function in autosomal-recessive parkinsonism causes mitochondrial 
dysfunction and increases PINK1/Parkin-dependent mitophagy. Am J Hum Genet 98:500-513. https://doi.org/10.1016/j.ajhg.2016.01.014

35. Levine IM, Estes JW, Looney JM (1968) Hereditary neurological disease with acanthocytosis. A new syndrome. Arch Neurol 19:403-409

36. Li X, He S, Zhou X, Ye Y, Tan S, Zhang S, Li R, Yu M, Jundt MC, Hidebrand A, Wang Y, Li G, Huang C, Wu M (2016) Lyn delivers bacteria to lysosomes for eradication through TLR2-initiated autophagy related phagocytosis. PLoS Pathog 12:e1005363. https://doi.org/10.1371/journal.ppat.1005363

37. Lichtenstein A, Minogue PJ, Beyer EC, Berthoud VM (2011) Autophagy: a pathway that contributes to connexin degradation. J Cell Sci 124:910920. https://doi.org/10.1242/jcs.073072

38. Liu J, Heinsen H, Grinberg LT, Alho E, Amaro E Jr, Pasqualucci CA, Rub U, den Dunnen W, Arzberger T, Schmitz C, Kiessling M, Bader B, Danek A (2018) Subcortical neurodegeneration in chorea: similarities and differences between chorea-acanthocytosis and Huntington's disease. Parkinsonism Relat Disord 49:54-59. https://doi.org/10.1016/j.parkreldis. 2018.01.009

39. Liu J, Heinsen H, Grinberg LT, Alho E, Amaro E Jr, Pasqualucci CA, Rub U, Seidel K, den Dunnen W, Arzberger T, Schmitz C, Kiessling MC, Bader B, Danek A (2018) Pathoarchitectonics of the cerebral cortex in choreaacanthocytosis and HD. Neuropathol Appl Neurobiol. https://doi.org/10. 1111/nan.12495

40. Lonskaya I, Hebron ML, Desforges NM, Franjie A, Moussa CE (2013) Tyrosine kinase inhibition increases functional parkin-Beclin-1 interaction and enhances amyloid clearance and cognitive performance. EMBO Mol Med 5:1247-1262. https://doi.org/10.1002/emmm.201302771

41. Lu W, Fang W, Li J, Zhang B, Yang Q, Yan X, Peng L, Ai H, Wang JJ, Liu X, Luo J, Yang W (2015) Phosphorylation of tyrosine 1070 at the GluN2B subunit is regulated by synaptic activity and critical for surface expression of N-methyl-D-aspartate (NMDA) receptors. J Biol Chem 290:22945-22954. https://doi.org/10.1074/jbc.M115.663450

42. Lupo F, Tibaldi E, Matte A, Sharma AK, Brunati AM, Alper SL, Zancanaro C, Benati D, Siciliano A, Bertoldi M, Zonta F, Storch A, Walker RH, Danek A, Bader B, Hermann A, De Franceschi L (2016) A new molecular link between defective autophagy and erythroid abnormalities in chorea-acanthocytosis. Blood 128:2976-2987. https://doi.org/10.1182/ blood-2016-07-727321

43. Matte A, Federti E, Winter M, Koerner A, Harmeier A, Mazer N, Tomka T, Di Paolo ML, De Falco L, Andolfo I, Beneduce E, lolascon A, Macias-Garcia A, Chen JJ, Janin A, Lebouef C, Turrini F, Brugnara C, De Franceschi L (2019) Bitopertin, a selective oral GLYT1 inhibitor, improves anemia in a mouse model of $\beta$-thalassemia. JCI Insight. https://doi.org/10.1172/jci.insight. 130111

44. Matte A, Low PS, Turrini F, Bertoldi M, Campanella ME, Spano D, Pantaleo A, Siciliano A, De Franceschi L (2010) Peroxiredoxin-2 expression is increased in beta-thalassemic mouse red cells but is displaced from the membrane as a marker of oxidative stress. Free Radic Biol Med 49:457-466. https://doi.org/10.1016/j.freeradbiomed.2010.05.003

45. McKnight NC, Zhong Y, Wold MS, Gong S, Phillips GR, Dou Z, Zhao Y, Heintz N, Zong WX, Yue Z (2014) Beclin 1 is required for neuron viability and regulates endosome pathways via the UVRAG-VPS34 complex. PLoS Genet 10:e1004626. https://doi.org/10.1371/journal.pgen.1004626

46. Mo Y, Sun YY, Liu KY (2020) Autophagy and inflammation in ischemic stroke. Neural Regen Res 15:1388-1396. https://doi.org/10.4103/16735374.274331

47. Ninkina N, Peters O, Millership S, Salem H, van der Putten H, Buchman VL (2009) Gamma-synucleinopathy: neurodegeneration associated with overexpression of the mouse protein. Hum Mol Genet 18:1779-1794. https://doi.org/10.1093/hmg/ddp090

48. Oeckl P, Metzger F, Nagl M, von Arnim CA, Halbgebauer S, Steinacker $P$, Ludolph AC, Otto M (2016) Alpha-, beta-, and gamma-synuclein quantification in cerebrospinal fluid by multiple reaction monitoring reveals increased concentrations in Alzheimer's and Creutzfeldt-Jakob disease but no alteration in synucleinopathies. Mol Cell Proteomics 15:31263138. https://doi.org/10.1074/mcp.M116.059915

49. Pagan FL, Hebron ML, Wilmarth B, Torres-Yaghi Y, Lawler A, Mundel EE, Yusuf N, Starr NJ, Anjum M, Arellano J, Howard HH, Shi W, Mulki S, KurdMisto T, Matar S, Liu X, Ahn J, Moussa C (2019) Nilotinib effects on safety, tolerability, and potential biomarkers in Parkinson disease: a phase 2 randomized clinical trial. JAMA Neurol. https://doi.org/10.1001/jaman eurol.2019.4200
50. Peikert K, Danek A, Hermann A (2017) Current state of knowledge in chorea-acanthocytosis as core neuroacanthocytosis syndrome. Eur J Med Genet. https://doi.org/10.1016/j.ejmg.2017.12.007

51. Pellerin L, Magistretti PJ (2012) Sweet sixteen for ANLS. J Cereb Blood Flow Metab Off J Int Soc Cereb Blood Flow Metab 32:1152-1166. https:// doi.org/10.1038/jcbfm.2011.149

52. Peters OM, Shelkovnikova T, Highley JR, Cooper-Knock J, Hortobagyi T, Troakes C, Ninkina N, Buchman VL (2015) Gamma-synuclein pathology in amyotrophic lateral sclerosis. Ann Clin Transl Neurol 2:29-37. https://doi. org/10.1002/acn3.143

53. Rampoldi L, Danek A, Monaco AP (2002) Clinical features and molecular bases of neuroacanthocytosis. J Mol Med (Berl) 80:475-491. https://doi. org/10.1007/s00109-002-0349-z

54. Rampoldi L, Dobson-Stone C, Rubio JP, Danek A, Chalmers RM, Wood NW, Verellen C, Ferrer X, Malandrini A, Fabrizi GM, Brown R, Vance J, PericakVance M, Rudolf G, Carrè S, Alonso E, Manfredi M, Németh AH, Monaco AP (2001) A conserved sorting-associated protein is mutant in choreaacanthocytosis. Nat Genet 28:119. https://doi.org/10.1038/88821

55. Ravikumar B, Imarisio S, Sarkar S, O'Kane CJ, Rubinsztein DC (2008) Rab5 modulates aggregation and toxicity of mutant huntingtin through macroautophagy in cell and fly models of Huntington disease. J Cell Sci 121:1649-1660. https://doi.org/10.1242/jcs.025726

56. Russell RC, Tian Y, Yuan H, Park HW, Chang YY, Kim J, Kim H, Neufeld TP, Dillin A, Guan KL (2013) ULK1 induces autophagy by phosphorylating Beclin-1 and activating VPS34 lipid kinase. Nat Cell Biol 15:741-750. https://doi.org/10.1038/ncb2757

57. Russell RC, Yuan HX, Guan KL (2014) Autophagy regulation by nutrient signaling. Cell Res 24:42-57. https://doi.org/10.1038/cr.2013.166

58. Salminen A, Kaarniranta K, Kauppinen A, Ojala J, Haapasalo A, Soininen H, Hiltunen M (2013) Impaired autophagy and APP processing in Alzheimer's disease: the potential role of Beclin 1 interactome. Prog Neurobiol 106-107:33-54. https://doi.org/10.1016/j.pneurobio.2013.06.002

59. Salter MW, Kalia LV (2004) Src kinases: a hub for NMDA receptor regulation. Nat Rev Neurosci 5:317-328. https://doi.org/10.1038/nrn1368

60. Schwenk BM, Hartmann H, Serdaroglu A, Schludi MH, Hornburg D, Meissner F, Orozco D, Colombo A, Tahirovic S, Michaelsen M, Schreiber F, Haupt S, Peitz M, Brustle O, Kupper C, Klopstock T, Otto M, Ludolph AC, Arzberger T, Kuhn PH, Edbauer D (2016) TDP-43 loss of function inhibits endosomal trafficking and alters trophic signaling in neurons. EMBO J 35:2350-2370. https://doi.org/10.15252/embj.201694221

61. Shibata M, LuT, Furuya T, Degterev A, Mizushima N, Yoshimori T, MacDonald M, Yankner B, Yuan J (2006) Regulation of intracellular accumulation of mutant Huntingtin by Beclin 1. J Biol Chem 281:14474-14485. https://doi. org/10.1074/jbc.M600364200

62. Simuni T, Fiske B, Merchant K, Coffey CS, Klingner E, Caspell-Garcia C, Lafontant DE, Matthews H, Wyse RK, Brundin P, Simon DK, Schwarzschild M, Weiner D, Adams J, Venuto C, Dawson TM, Baker L, Kostrzebski M, Ward T, Rafaloff G, Parkinson Study Group N-PDI, Collaborators (2020) Efficacy of nilotinib in patients with moderately advanced Parkinson disease: a randomized clinical trial. JAMA Neurol. https://doi.org/10.1001/jaman eurol.2020.4725

63. Spencer B, Potkar R, Trejo M, Rockenstein E, Patrick C, Gindi R, Adame A, Wyss-Coray T, Masliah E (2009) Beclin 1 gene transfer activates autophagy and ameliorates the neurodegenerative pathology in alpha-synuclein models of Parkinson's and Lewy body diseases. J Neurosci Off J Soc Neurosci 29:13578-13588. https://doi.org/10.1523/jneurosci.4390-09.2009

64. Stanslowsky N, Reinhardt P, Glass H, Kalmbach N, Naujock M, Hensel N, Lubben V, Pal A, Venneri A, Lupo F, De Franceschi L, Claus P, Sterneckert J, Storch A, Hermann A, Wegner F (2016) Neuronal dysfunction in iPSCderived medium spiny neurons from chorea-acanthocytosis patients is reversed by Src kinase inhibition and F-actin stabilization. J Neurosci 36:12027-12043. https://doi.org/10.1523/JNEUROSCI.0456-16.2016

65. Stenmark H (2009) Rab GTPases as coordinators of vesicle traffic. Nat Rev Mol Cell Biol 10:513-525. https://doi.org/10.1038/nrm2728

66. Tomemori Y, Ichiba M, Kusumoto A, Mizuno E, Sato D, Muroya S, Nakamura M, Kawaguchi H, Yoshida H, Ueno S, Nakao K, Nakamura K, Aiba A, Katsuki M, Sano A (2005) A gene-targeted mouse model for choreaacanthocytosis. J Neurochem 92:759-766. https://doi.org/10.1111/j.14714159.2004.02924.x

67. Turner RS, Hebron ML, Lawler A, Mundel EE, Yusuf N, Starr JN, Anjum M, Pagan F, Torres-Yaghi Y, Shi W, Mulki S, Ferrante D, Matar S, Liu X, Esposito 
G, Berkowitz F, Jiang X, Ahn J, Moussa C (2020) Nilotinib effects on safety, tolerability, and biomarkers in Alzheimer's disease. Ann Neurol 88:183-194. https://doi.org/10.1002/ana.25775

68. Ueno S, Maruki Y, Nakamura M, Tomemori Y, Kamae K, Tanabe H, Yamashita Y, Matsuda S, Kaneko S, Sano A (2001) The gene encoding a newly discovered protein, chorein, is mutated in chorea-acanthocytosis. Nat Genet 28:121. https://doi.org/10.1038/88825

69. Vandeputte C, Taymans JM, Casteels C, Coun F, Ni Y, Van Laere K, Baekelandt V (2010) Automated quantitative gait analysis in animal models of movement disorders. BMC Neurosci 11:92. https://doi.org/10.1186/ 1471-2202-11-92

70. Velayos Baeza A, Dobson-Stone C, Rampoldi L, Bader B, Walker RH, Danek A, Monaco AP (1993) Chorea-acanthocytosis. In: Adam MP, Ardinger HH, Pagon RA et al (eds) GeneReviews. University of Washington, Seattle

71. Walker RH (2015) Management of neuroacanthocytosis syndromes. Tremor Other Hyperkinetic Mov (New York, NY) 5:346. https://doi.org/10. 7916/d8w66k48

72. Wu Z, Chang PC, Yang JC, Chu CY, Wang LY, Chen NT, Ma AH, Desai SJ, Lo SH, Evans CP, Lam KS, Kung HJ (2010) Autophagy blockade sensitizes prostate cancer cells towards Src family kinase inhibitors. Genes Cancer 1:40-49. https://doi.org/10.1177/1947601909358324

73. Yeatman TJ (2004) A renaissance for SRC. Nat Rev Cancer 4:470-480. https://doi.org/10.1038/nrc1366

74. Yeshaw WM, van der Zwaag M, Pinto F, Lahaye LL, Faber Al, GomezSanchez R, Dolga AM, Poland C, Monaco AP, van IJzendoorn SCD, Grzeschik NA, Velayos-Baeza A, Sibon OC (2019) Human VPS13A is associated with multiple organelles and influences mitochondrial morphology and lipid droplet motility. eLife. https://doi.org/10.7554/eLife.43561

75. Zhu W, Smith JW, Huang CM (2010) Mass spectrometry-based label-free quantitative proteomics. J Biomed Biotechnol 2010:840518. https://doi. org/10.1155/2010/840518

\section{Publisher's Note}

Springer Nature remains neutral with regard to jurisdictional claims in published maps and institutional affiliations.
Ready to submit your research? Choose BMC and benefit from:

- fast, convenient online submission

- thorough peer review by experienced researchers in your field

- rapid publication on acceptance

- support for research data, including large and complex data types

- gold Open Access which fosters wider collaboration and increased citations

- maximum visibility for your research: over $100 \mathrm{M}$ website views per year

At BMC, research is always in progress.

Learn more biomedcentral.com/submissions 